Article

\title{
Effect of Pasteurisation on Methane Yield from Food Waste and Other Substrates in Anaerobic Digestion
}

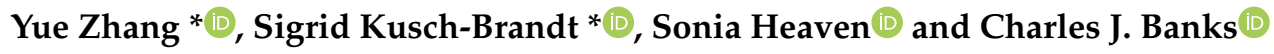 \\ Water and Environmental Engineering Group, University of Southampton, Southampton SO16 7QF, UK; \\ S.Heaven@soton.ac.uk (S.H.); C.J.Banks@soton.ac.uk (C.J.B.) \\ * Correspondence: Y.Zhang@soton.ac.uk (Y.Z.); mail@sigrid-kusch.eu (S.K.-B.)
}

Received: 10 September 2020; Accepted: 23 October 2020; Published: 26 October 2020

\begin{abstract}
The effect of pasteurisation and co-pasteurisation on biochemical methane potential values in anaerobic digestion (AD) was studied. Pasteurisation prior to digestion in a biogas plant is a common hygienisation method for organic materials which contain or have been in contact with animal by-products. Tests were carried out on food waste, slaughterhouse waste, animal blood, cattle slurry, potato waste, card packaging and the organic fraction of municipal solid waste (OFMSW); pasteurisation at $70{ }^{\circ} \mathrm{C}$ for $1 \mathrm{~h}$ was applied. Pasteurisation had increased the methane yields of blood $(+15 \%)$ and potato waste $(+12 \%)$ only, which both had a low content of structural carbohydrates (hemi-cellulose and cellulose) but a particularly high content of either non-structural carbohydrates such as starch (potato waste) or proteins (blood). With food waste, card packaging and cattle slurry, pasteurisation had no observable impact on the methane yield. Slaughterhouse waste and OFMSW yielded less methane after pasteurisation in the experiments (but statistical significance of the difference between pasteurised and unpasteurised slaughterhouse waste or OFMSW was not confirmed in this work). It is concluded that pasteurisation can positively impact the methane yield of some specific substrates, such as potato waste, where heat-treatment may induce gelatinisation with release of the starch molecules. For most substrates, however, pasteurisation at $70{ }^{\circ} \mathrm{C}$ is unlikely to increase the methane yield. It is unlikely to improve biodegradability of lignified materials, and it may reduce the methane yield from substrates which contain high contents of volatile components. Furthermore, in this experimental study, the obtained methane yield was unaffected by whether the substrates were pasteurised individually and then co-digested or co-pasteurised as a mixture before batch digestion.
\end{abstract}

Keywords: food waste; anaerobic digestion; pasteurisation; methane yield; animal by-products regulation

\section{Introduction}

Anaerobic digestion (AD), which yields both biogas as energy carrier and digestate as valuable soil amendment, is a suitable and frequently implemented valorisation pathway for food waste and organic by-products occurring along the food supply chain. However, organic residues which embody meat or meat products or have been contaminated by such materials, or which originate from livestock breeding, can contain pathogenic microorganisms that are of sanitary concern when applying AD digestate to agricultural land [1,2]. Through contamination of plants grown on agricultural land, infectious microorganisms in AD digestate can cause outbreaks of human or animal diseases $[3,4]$. To prevent such spreading of disease, hygienisation is required. This can be achieved through thermal hygienisation; chemical treatment such as ozonation; electro-technology such as pulsed electrical field or high-voltage discharge; or physico-chemical methods such as ultrasound technology, microwave irradiation or hydrostatic pressure [1]. Thermal hygienisation is most commonly applied [5]; it is 
a relatively straightforward choice for $\mathrm{AD}$ plants, as the digestion process itself produces enough energy to enable such treatment on site. In some countries, hygienisation is mandatory when processing animal by-products, and AD plant operators accepting such materials are obliged to respect the animal by-products regulations (ABPR). In the European Union (EU), pasteurisation at $70^{\circ} \mathrm{C}$ for $1 \mathrm{~h}$, applied to substrate where a particle size of maximum $12 \mathrm{~mm}$ is ensured, is the defined standard for meat-containing wastes from food processing, food waste from households and restaurants and slaughterhouse waste of animals which had been fit to deliver products for human consumption $[6,7]$.

Where organic material undergoes pasteurisation, the impact is not limited to the hygienisation effect. Pasteurisation, as a thermal pre-treatment, affects the physical and chemical structure of the feedstock itself, which can potentially impact biodegradability of the material during the processing in the AD reactor and consequently the methane yield obtained from that biomass [8]. The pre-treatment may alter morphology of the substrate particles [9], enhance solubilisation of the organic material and facilitate accessibility for microorganisms [1,10], thus accelerating hydrolysis in the AD plant. Conversion of complex substances into simpler ones, such as proteins into amino acids or long-chain-fatty acids into volatile fatty acids, can already occur during the pasteurisation step [1], or the pasteurisation might induce more rapid conversion of substrate after initiation of the $\mathrm{AD}$ process. The effect on $\mathrm{AD}$ performance is difficult to predict, but an impact on process kinetics can be expected. Accelerated hydrolysis might translate into accelerated biogas production, which has been observed for pasteurised sewage sludge [11]; however, more rapid hydrolysis also increases the risk of an accumulation of potentially inhibitory substances, such as volatile fatty acids (VFA) degraded from long chain fatty acids or ammonia originating from proteins [12]. While such inhibitory effects might be recoverable phenomena, they would cause a delayed production of biogas and potentially incomplete degradation of substrate $[8,13]$.

The review of Liu et al. [1] found only a small number of studies addressing the effect of pasteurisation on biogas production. Some reported an enhanced AD performance after pasteurisation of slaughterhouse waste, sewage sludge, cattle slurry or mixtures of substrates, with an increase in methane yield that usually ranged between marginal values and 50\% [1,14-18]. Other studies found no impact of pasteurisation on methane yield from slaughterhouse waste $[8,10,19]$, animal slurry $[1,12]$ or sewage sludge [1]. For slaughterhouse waste and sewage sludge, however, some studies reported negative effects with a drop in methane yield when using pasteurised substrate [1,12,20]. Liu et al. [1] concluded that thermal pre-treatment of wastes that are rich in protein and grease might generate critically elevated concentrations of acids or ammonia, with the risk of inhibiting the methanogenic process during AD. Rodriguez-Abalde et al. [21] studied slaughterhouse by-products which differed in protein and carbohydrate concentrations; they observed improvement in organic matter solubilisation for all substrate types, but only the materials with low carbohydrate contents showed higher methane yield after thermal pre-treatment, while no significant methane increase occurred after thermal pre-treatment when carbohydrate content of the biomass was high. They concluded that the observed reduction in bioavailability for wastes with a high carbohydrate content might be due to the formation of low-biodegradability compounds through Maillard reactions during thermal pre-treatment, i.e., chemical reactions between the carbohydrates (sugars) and amino acids from proteins. Maillard reactions depend on ambient conditions such as temperature, $\mathrm{pH}$ and water activity [22] and have been reported to occur at $100^{\circ} \mathrm{C}$ or lower [22-24], including at around $60^{\circ} \mathrm{C}[25,26]$, i.e., at temperature levels which include $70^{\circ} \mathrm{C}$ (pasteurisation temperature). However, the picture is still incomplete [1].

Food waste is among the most ubiquitous energy-rich organic materials suitable for AD [27-29]. Food waste is an attractive choice for co-digestion due to the relatively high biogas yield of this substrate [30-33]. At agricultural AD plants, where economic viability is difficult to achieve with manure or slurry feedstocks alone, taking in food waste is a favourable option [34]. In the EU, food waste from households, restaurants and industry falls under ABPR hygienisation requirements, with pasteurisation at $70^{\circ} \mathrm{C}$ as a standard. AD of food waste for biogas production has been widely studied, but the effect of pasteurisation on biogas production has not previously been researched. 
Zarkadas et al. [35] examined the performance of pasteurised food waste when co-digested with cattle slurry and observed very good performance up to a ratio of $25 \%$ food waste by wet weight; however, they did not digest unpasteurised food waste, and also not food waste alone. Pagliaccia et al. [36] reported a reduction of the methane yield obtained in mesophilic AD after thermal pre-treatment of food waste, which occurred along with an increased initial hydrogen production in response to the carbohydrate solubilisation; however, the pre-treatment was conducted at $134{ }^{\circ} \mathrm{C}$ and a pressure of 3.2 bar, and thus might not occur for standard pasteurisation at $70^{\circ} \mathrm{C}$.

The available studies about the impact of pasteurisation on $\mathrm{AD}$ are based on a few selected organic materials and the findings are partially contradictory and difficult to interpret $[1,10]$. One possible explanation for the variations among the findings is that methodologies applied, and experimental methods used, were not the same [1]. Furthermore, in some studies, the duration of the experiments was too short to allow reliable conclusions about the ultimate methane yield from pasteurised material [8]. Other studies applied co-digestion of pasteurised substrates but did not study the performance of individual substrates.

The existing knowledge in this area is thus uncertain and incomplete, making it difficult for the $\mathrm{AD}$ industry to assess the impact of pasteurisation in the development of biogas production technology. While pasteurisation is required in many cases under the ABPR, it is often justified as potentially increasing the methane yield, and thus contributing to a more favourable energy balance of the AD process. The body of knowledge to support or criticise this argument, however, is insufficient, and thus this work contributes to closing this knowledge gap. This research therefore involved parallel testing of the experimentally obtained biochemical methane potential (BMP) of a range of common waste types under standardised conditions to allow for more informed assessment of whether pasteurisation/co-pasteurisation is likely to affect the methane yield and kinetic aspects of anaerobic degradation. Processing the different materials in parallel under standardised conditions contributes to closing the existing knowledge gap regarding the specific performance of different types of materials that are commonly subjected to pasteurisation before AD. This supports full-scale plant operators to understand the implications of pasteurisation regarding methane production of the AD plant when processing different types of wastes, and it also contributes to identifying further research needs in this field.

\section{Materials and Methods}

BMP testing was conducted on source-separated domestic food waste, slaughterhouse waste (consisting of pig gut with flotation fat), animal blood, cattle slurry, potato waste, card packaging and on the organic fraction of municipal solid waste (OFMSW) recovered in a mechanical biological treatment (MBT) plant. Potato waste, which is not an animal by-product but a vegetable waste, was included in the study, because in the UK, it is a high-volume organic residue stream in the food sector, and due to its low nitrogen content, it has been suggested as a suitable co-substrate to accompany in the biogas plant the digestion of food waste or slaughterhouse waste (susceptible to AD inhibition due to high nitrogen content) [37]. Card packaging was included because it can be collected together with food waste and, again, as co-substrate can favourably lower the nitrogen content in AD when digesting food waste or slaughterhouse waste [37].

\subsection{Materials}

The rationale for the choice of substrates is explained above (more background information is available in the technical report of the project [37]), while the following documents the origin and characteristics of the materials.

Food waste: Source-separated domestic food waste $(210 \mathrm{~kg})$ was obtained from the environmental services provider Cwm Harry Estates, Newtown, Powys, UK. The food waste was collected on site and transported in sealed drums to the laboratory of University of Southampton. 
Slaughterhouse waste: Two batches of pig gut (each with a weight of around $8 \mathrm{~kg}$, and one batch of recovered fat $(5 \mathrm{~kg})$ were obtained from the slaughterhouse Grampian Country Pork-Case, Taunton, Somerset, UK. At this slaughterhouse, the average annual arising of pig gut waste is around 800 tonnes and around two tonnes of fat are captured in the facility's fat traps per year. At the company site, there were no further process steps (e.g., dissolved air flotation) to remove fat from the generated slaughterhouse wastewater stream, and, thus, in this study, it was assumed that the retrieved trap material is representative of separable fat occurring at slaughterhouses. Sampled pig gut and recovered fat were mixed to represent the slaughterhouse waste. In the current study, the proportion of mixed gut and fat used was 9:1, respectively, on a VS (volatile solids) basis.

Animal blood: Sheep blood (20 kg) was obtained from an abattoir in Farnborough, Hampshire, UK (operating company R.W. Newman and Partners).

Cattle slurry: A $20 \mathrm{~kg}$ sample of fresh material was obtained from a dairy farm (Parkers Farm, Hampshire, UK). Using a tractor-mounted scraper, the slurry was secured from the milking area at the farm immediately after the milking was done.

Potato waste: A $2 \mathrm{~kg}$ sample was provided by Forest Products Ltd., Dorset, UK. The potato waste consisted of raw potato chip (before frying) rejected for the manufacturing of crisps and was essentially a two-dimensional material (slice thickness of around $0.5 \mathrm{~mm}$ ).

Card packaging: $100 \mathrm{~kg}$ of card packaging mixture was retrieved from the Materials Recovery Facility (MRF) in Alton, Hampshire, UK (operated by Veolia Environmental Services (UK) Ltd.,). This mixed card packaging, which is a reject stream from the MRF, was sorted into three fractions, namely, corrugated cardboard as one fraction, card packaging as another fraction and other card as the third fraction; then, the material was blended in proportions of $29.6 \%, 62.5 \%$ and $7.9 \%$, respectively, on a fresh weight basis, based on previous waste compositional studies regarding the average card packaging waste in the UK [37].

Organic fraction of municipal solid waste (OFMSW): $100 \mathrm{~kg}$ of mechanically recovered OFMSW was collected from Bursom Recycling Centre, Leicester, UK. This was the organic fraction remaining after pre-processing of municipal solid waste to recover plastic, paper and card, glass and metal using a combination of processes including a ball mill, magnetic separator, ballistic separator, and eddy current separator. The mean particle size of the OFMSW was $6.0 \mathrm{~mm}$, with most of the particles $(>99 \%)$ being below $13.2 \mathrm{~mm}$ [38].

Wastes were transported to the laboratory of University of Southampton and either processed immediately (same day) or stored overnight in a cold room $\left(3^{\circ} \mathrm{C} \pm 1{ }^{\circ} \mathrm{C}\right)$. To homogenise the substrate, each of the samples was thoroughly mixed, with any agglomerates formed during transportation being gently broken up. A macerating grinder was used for the wet materials (S52/010 Waste Disposer, Imperial Machine Company Ltd., Hertfordshire, UK). Where necessary, material dimensions were reduced by coarse cutting by hand or using mills. Physico-chemical characterisation of substrates was accomplished using the methods described below. Analyses were conducted in triplicate or more for food waste and OFMSW in most cases (some parameters considered in duplicate only due to operational problems; $\mathrm{pH}$ done in duplicate only); for the other substrates, parameters were analysed in triplicate or in replicate (as Supplementary Materials, the full data set is available on the open access repository of University of Southampton: https://doi.org/10.5258/SOTON/D1603). Table 1 shows the substrate characteristics (average values with standard deviations). 
Table 1. Characteristics of the substrates used in this study (WW: wet weight; TS: total solids; VS: volatile solids; TOC: total organic carbon; TAN: total ammoniacal nitrogen; TKN: total Kjeldahl nitrogen; Biodegradable C: biodegradable carbon; TP: total phosphorous; TK: total potassium; CV: calorific value).

\begin{tabular}{|c|c|c|c|c|c|c|c|}
\hline & Food Waste & Slaughter-House Waste $^{1}$ & Animal Blood $^{2}$ & Cattle Slurry & Potato Waste & Card Packaging & OFMSW \\
\hline \multicolumn{8}{|c|}{ Basic characteristics relevant for anaerobic digestion including nutrients } \\
\hline $\mathrm{pH}$ & $4.71 \pm 0.01(1: 5)^{3}$ & $5.96 \pm 0.04(1: 5)^{3}$ & $7.23 \pm 0.06$ & $7.83 \pm 0.07(1: 5)^{3}$ & $8.12 \pm 0.01(1: 5)^{3}$ & $7.21 \pm 0.03(1: 30)^{3}$ & $6.39 \pm 0.01(1: 5)^{3}$ \\
\hline TS $(\%$ WW) & $23.7 \pm 0.1$ & $20.8 \pm 0.3$ & $19.7 \pm 0.3$ & $9.31 \pm 0.14$ & $24.7 \pm 0.0$ & $93.9 \pm 0.1$ & $52.8 \pm 0.6$ \\
\hline VS (\% WW) & $21.7 \pm 0.1$ & $19.4 \pm 0.3$ & $18.9 \pm 0.3$ & $6.52 \pm 0.04$ & $23.1 \pm 0.0$ & $78.5 \pm 0.4$ & $33.6 \pm 0.6$ \\
\hline TOC (\% TS) & $47.6 \pm 0.5$ & $45.5 \pm 1.7$ & $41.9 \pm 0.7$ & $38.9 \pm 1.0$ & $42.7 \pm 1.1$ & $41.6 \pm 0.7$ & $35.0 \pm 0.4$ \\
\hline TAN (\% TS) & - & - & - & $1.15 \pm 0.01$ & - & - & - \\
\hline TKN (\% TS) & $3.42 \pm 0.04$ & $7.95 \pm 0.12$ & $14.7 \pm 0.0$ & $3.50 \pm 0.05$ & $1.53 \pm 0.01$ & $0.144 \pm 0.001$ & $1.39 \pm 0.08$ \\
\hline $\mathrm{TP}\left(\mathrm{g} \mathrm{kg}^{-1} \mathrm{TS}\right)$ & $5.41 \pm 0.32$ & $8.10 \pm 0.13$ & $0.835 \pm 0.036$ & $8.58 \pm 0.63$ & $3.59 \pm 0.48$ & $0.134 \pm 0.003$ & $2.17 \pm 0.25$ \\
\hline $\mathrm{TK}\left(\mathrm{g} \mathrm{kg}^{-1} \mathrm{TS}\right)$ & $14.3 \pm 0.8$ & $10.9 \pm 0.1$ & $3.71 \pm 0.11$ & $16.7 \pm 0.2$ & $23.8 \pm 0.8$ & $0.221 \pm 0.011$ & $4.26 \pm 0.37$ \\
\hline Biodegradable C/TKN & $13.6 \pm 0.3$ & $5.58 \pm 0.25$ & $2.85 \pm 0.05$ & $8.12 \pm 2.00$ & $27.5 \pm 0.8$ & $207 \pm 54$ & $19.6 \pm 3.9$ \\
\hline $\mathrm{CV}\left(\mathrm{kJ} \mathrm{g}^{-1} \mathrm{TS}\right)$ & $20.66 \pm 0.18$ & $26.21 \pm 0.01$ & $22.91 \pm 0.25$ & $16.75 \pm 0.10$ & $16.50 \pm 0.10$ & $17.18 \pm 0.36$ & $13.90 \pm 0.23$ \\
\hline \multicolumn{8}{|c|}{ Biochemical composition of substrates, expressed on a VS basis (in $\mathrm{g} \mathrm{kg}^{-1} \mathrm{VS}$ ) } \\
\hline Non-structural carbohydrates 4 & $508.9 \pm 4.9$ & $<10$ & $25.1 \pm 2.2$ & $144.5 \pm 12.0$ & $832.0 \pm 3.7$ & 14.6 & $313.2 \pm 47.1$ \\
\hline Lipids ${ }^{5}$ & $151.2 \pm 0.9$ & $348.9 \pm 7.6$ & $<10$ & $93.6 \pm 0.8$ & $<10$ & $<10$ & $68.6 \pm 5.4$ \\
\hline Crude proteins & $235.0 \pm 2.6$ & $537.6 \pm 7.8$ & $964.9 \pm 2.2$ & $213.5 \pm 3.7$ & $102.7 \pm 0.3$ & $10.8 \pm 0.0$ & $130.0 \pm 7.4$ \\
\hline Hemi-cellulose & $38.1 \pm 3.7$ & $46.3 \pm 2.9$ & - & $225.6 \pm 8.2$ & $22.0 \pm 0.4$ & $127.8^{6}$ & $52.2 \pm 12.3$ \\
\hline Cellulose & $50.4 \pm 1.6$ & $46.0 \pm 4.0$ & - & $96.7 \pm 3.0$ & $22.1 \pm 2.8$ & $623.9^{6}$ & $252.0 \pm 36.2$ \\
\hline Lignin & $16.5 \pm 0.2$ & $18.5 \pm 2.1$ & - & $226.1 \pm 7.3$ & $11.2 \pm 2.3$ & $212.9^{6}$ & $184.0 \pm 25.9$ \\
\hline \multicolumn{8}{|c|}{ Elemental analysis (in \% of TS) } \\
\hline $\mathrm{C}$ & $47.9 \pm 0.5$ & $45.6 \pm 1.7$ & $42.1 \pm 0.7$ & $39.2 \pm 1.0$ & $43.7 \pm 1.1$ & $41.6 \pm 0.7$ & $35.1 \pm 0.5$ \\
\hline $\mathrm{H}$ & $7.03 \pm 0.26$ & $8.04 \pm 0.38$ & $7.33 \pm 0.37$ & $5.18 \pm 0.15$ & $7.18 \pm 0.20$ & $4.76 \pm 0.23$ & $5.06 \pm 0.32$ \\
\hline $\mathrm{S}$ & $0.15 \pm 0.01$ & $0.62 \pm 0.03$ & $1.00 \pm 0.02$ & $0.31 \pm 0.02$ & $0.06 \pm 0.02$ & $0.21 \pm 0.00$ & $0.27 \pm 0.04$ \\
\hline $\mathrm{O}$ & $34.3 \pm 2.5$ & $23.3 \pm 1.7$ & $27.1 \pm 0.9$ & $23.1 \pm 0.9$ & $38.8 \pm 1.3$ & $36.9 \pm 0.9$ & $25.1 \pm 1.2$ \\
\hline \multicolumn{8}{|c|}{ Potentially toxic elements (in mg kg${ }^{-1} \mathrm{TS}$ ) } \\
\hline $\mathrm{Cd}$ & $<1.0$ & $<1.0$ & $<1.0$ & $<1.0$ & $<1.0$ & $<0.05$ & $1.50 \pm 0.37$ \\
\hline $\mathrm{Cr}$ & $30.8 \pm 0.6$ & $14.6 \pm 0.3$ & $<2.0$ & $113 \pm 2$ & $6.9 \pm 0.5$ & $9.1 \pm 0.9$ & $263 \pm 11$ \\
\hline $\mathrm{Cu}$ & $7.20 \pm 0.81$ & $37.9 \pm 0.5$ & $6.7 \pm 0.3$ & $58.4 \pm 1.1$ & $9.8 \pm 0.7$ & $20.3 \pm 2.3$ & $107 \pm 10$ \\
\hline $\mathrm{Hg}$ & $<0.010$ & $<0.010$ & $<0.010$ & $<0.010$ & $<0.010$ & $<0.10$ & $0.179 \pm 0.018$ \\
\hline $\mathrm{Ni}$ & $7.0 \pm 2.9$ & $6.9 \pm 0.3$ & $<5.0$ & $44.8 \pm 0.6$ & $<5.0$ & $4.5 \pm 0.5$ & $97.0 \pm 2.9$ \\
\hline $\mathrm{Pb}$ & $<10$ & $<10$ & $<10$ & $<10$ & $<10$ & $2.9 \pm 0.4$ & $162 \pm 11$ \\
\hline $\mathrm{Zn}$ & $33 \pm 11$ & $250 \pm 0$ & $16.3 \pm 0.2$ & $231 \pm 6$ & $20.3 \pm 0.5$ & $16.2 \pm 4.3$ & $259 \pm 4$ \\
\hline
\end{tabular}

\footnotetext{
${ }_{5}^{1}$ Pig gut and flotation fat (mixture in 9:1 ratio on a VS basis). ${ }^{2}$ Sheep blood. ${ }^{3}$ Information
} 
The range of properties determined for the substrates is more extensive than typically available in similar work, providing a very detailed picture of the materials and valuable data on their constituents.

The inoculum was municipal wastewater biosolids digestate from a mesophilic $\left(35-37^{\circ} \mathrm{C}\right)$ anaerobic digester at Millbrook wastewater treatment plant, Southampton, UK. The collected digestate was strained through a $1 \mathrm{~mm}$ mesh before use, and then had the following characteristics: total solids (TS): $4.48 \pm 0.07 \%$ wet weight (WW), volatile solids (VS): $62.8 \pm 1.4 \% \mathrm{TS}$, total Kjeldahl nitrogen (TKN): $77.5 \pm 1.5 \mathrm{~g} \mathrm{~N} \mathrm{~kg}^{-1} \mathrm{TS}$, total phosphorous (TP): $32.4 \pm 3.5 \mathrm{~g} \mathrm{P} \mathrm{kg}^{-1} \mathrm{TS}$, total potassium (TK): $2.90 \pm 0.29 \mathrm{~g} \mathrm{~K} \mathrm{~kg}^{-1} \mathrm{TS}, \mathrm{Cd}: 1.10 \pm 0.21 \mathrm{mg} \mathrm{kg}^{-1} \mathrm{TS}, \mathrm{Cr}: 67.3 \pm 5.3 \mathrm{mg} \mathrm{kg}^{-1} \mathrm{TS}, \mathrm{Cu}: 462 \pm 9 \mathrm{mg} \mathrm{kg}^{-1}$ TS, Ni: $52.9 \pm 7.4 \mathrm{mg} \mathrm{kg}^{-1} \mathrm{TS}, \mathrm{Pb}: 83.8 \pm 8.4 \mathrm{mg} \mathrm{kg}^{-1} \mathrm{TS}, \mathrm{Zn}: 718 \pm 27 \mathrm{mg} \mathrm{kg}^{-1} \mathrm{TS}$.

\subsection{Pasteurisation Procedure}

The samples were treated in conformity with the minimum $\mathrm{AD}$ pasteurisation requirements in the EU animal by-products regulations (EU ABP Regulation 1774/2002, EU ABP Regulation 1069/2009) [6,7], ensuring pasteurisation at $70{ }^{\circ} \mathrm{C}$ for $1 \mathrm{~h}$. Around $500 \mathrm{~g}$ of each sample was held in a glass container covered with parafilm and equipped with a thermometer and a spatula for manual stirring. The sample was put in a water bath with the parafilm cover well above the water surface. The sample temperature was gradually raised to $72^{\circ} \mathrm{C} \pm 2{ }^{\circ} \mathrm{C}$ then maintained at this value for $1 \mathrm{~h}$. Manual stirring was performed without breaking the parafilm cover. The pasteurisation process was repeated for sub-samples of the batch of cattle slurry as the quantity required for BMP testing was high due to its low solids content. The total solids (TS) of the OFMSW and card packaging waste were reduced to $30 \%$ using deionised water before pasteurisation to facilitate the heat treatment. The volatile solids (VS) content of each pasteurised sample was measured again before the BMP test to take into account any small amounts of moisture evaporating and condensing on the parafilm cover during the pasteurisation process.

\subsection{Experimental Set-Up}

In total, fifty-seven continuously stirred laboratory digesters (each with 1.4 litres of working volume; 2 litres of total digester volume) were operated in batch mode to carry out the BMP tests. A detailed description of the digesters, including schematic diagram and photographic documentation, is available elsewhere [41]. Stirring was done at $40 \mathrm{rpm}$, using an asymmetric bar-type stirrer driven by a motor on each digester. The digesters were kept at constant temperature in a mesophilic range $\left(36{ }^{\circ} \mathrm{C} \pm 1{ }^{\circ} \mathrm{C}\right)$ in water baths. The BMP tests ran for 132 days (except for the BMP tests with cattle slurry, where the digestion period was shortened to 125 days; this small difference in the digestion time was due to laboratory management).

All tests were carried out at an inoculum-to-substrate (i/s) ratio of 4 on a VS basis, based on Zhang et al. [41]. Tests on pasteurised and unpasteurised materials were carried out in parallel, and each studied material was run in triplicate. In addition to the single substrates, food waste and cattle slurry were also co-digested, i.e., the performance of the mixture of these two substrates was studied. The mixture was tested both with the two components pasteurised separately and then mixed before the digestion and with the mixed components co-pasteurised (pasteurised as mixture) before the digestion. This was to allow identification of any synergistic or antagonistic effect due to the processing sequence, as well as comparison with the results for the individual substrates when processed separately.

Two digesters were also set up with pasteurised and unpasteurised food waste as the substrate to allow monitoring of the volatile fatty acid (VFA) profiles and the total ammonia nitrogen (TAN) concentrations over time.

The inoculum was digested separately in four replicates as a control, allowing determination of its residual methane production. In addition, a positive control was run in triplicate using a standard reference material to ensure that the overall test procedure was capable of giving valid results. The standard was a high purity cellulose powder fibrous in form and of medium particle size 
(Sigma-Aldrich Company Ltd., UK, product no. C6288, CAS 9004-34-6, EC no. 232-674-9). The results for this control, which are documented in Appendix A, confirmed that the test method was reliable.

\subsection{Determination of Biogas Production}

Biogas from the digesters was collected in calibrated glass collection cylinders over a salt solution (75\% saturated sodium chloride) that was acidified to $\mathrm{pH} 2$ to diminish dissolution of methane and other gases [42]. As a backup to manual readings of the biogas quantity, the height of the liquid column in each of the cylinders was recorded at intervals of $5 \mathrm{~min}$ using a headspace pressure sensor. Biogas and methane volumes are reported as standard volumes, i.e., as dry gas after correction for calculated water vapour content [42] and conversion to standard temperature and pressure (STP) $\left(101.325 \mathrm{kPa}, 0{ }^{\circ} \mathrm{C}\right)$. To enable the analysis of gas composition, samples were taken from the gas collection cylinders each time the cylinders were refilled, which was done at frequent intervals of maximum 7 days. Contents of methane and carbon dioxide in the biogas were determined using a Star 3400 CX Gas Chromatograph (Varian, Oxford, UK), equipped with a thermal conductivity detector (TCD); the gas chromatograph was fitted with a Hayesep $\mathrm{C}$ column and the carrier gas was argon at a flow of $50 \mathrm{~mL} \mathrm{~min}^{-1}$; for calibration, the standard gas contained $65 \% \mathrm{CH}_{4}$ and $35 \% \mathrm{CO}_{2}(v / v)(\mathrm{BOC}$, Guildford, UK).

Methane production by the test samples was corrected for the residual production from the inoculum by subtracting the average methane production of the four inoculum replicates from the measured production of the test digesters. Error bars in figures represent the standard deviation of replicates, and values are reported as average of the replicates with standard deviation.

To interpret whether the difference in methane yield between pasteurised and unpasteurised samples of the same substrate is statistically significant, Student's $t$-test (unpaired, two-tailed) was applied, and the $p$-values are reported (where a $p$-value below 0.05 indicates a statistically significant difference at the confidence level of $95 \%$ ).

Theoretical methane yield of substrates was calculated by making use of their biochemical composition, applying the Buswell equation [43] (more information is available in an earlier publication [27]).

\subsection{Laboratory Analyses}

The content in total solids (TS) and the content in volatile solids (VS) were determined by applying Standard Method 2540 G [44]. For pH measurement, a combination glass electrode was used, after calibration of the electrode in buffers at $\mathrm{pH} \mathrm{4,7}$ and 9; non-liquid materials were mixed with deionised water and stirred for $1 \mathrm{~h}$ using magnetic stirrer at room temperature before measuring the $\mathrm{pH}$ (the mass ratio of substrate to deionised water is indicated in Table 1). Total Kjeldahl nitrogen (TKN) and total ammonia nitrogen (TAN) were measured using Kjeltech block digestion and steam distillation units, operated as recommended by the manufacturer (Foss Ltd., Warrington, UK). The content of crude proteins was calculated by multiplying the difference between TKN and TAN by 6.25 [45]. Quantification of volatile fatty acids (VFA), namely acetic, propionic, butyric, valeric, hexanoic and heptanoic acids, was performed using a Shimazdu GC-2010 gas chromatograph (Shimadzu, Milton Keynes, UK) with a flame ionization detector (FID) and capillary column type SGE BP-21; helium was used as the carrier gas at a flow rate of $190.8 \mathrm{~mL} \mathrm{~min}^{-1}$ and a split ratio of 100 to give a flow rate in the column of $1.86 \mathrm{~mL} \mathrm{~min}^{-1}$ with a purge of $3.0 \mathrm{~mL} \mathrm{~min}{ }^{-1}$; the GC oven temperature was raised from $60^{\circ} \mathrm{C}$ to $210^{\circ} \mathrm{C}$ in $15 \mathrm{~min}$ with a final hold time of $3 \mathrm{~min}$; injector and FID temperatures were $200{ }^{\circ} \mathrm{C}$ and $250^{\circ} \mathrm{C}$, respectively; for calibration, a standard solution was used which contained acetic, propionic, iso-butyric, n-butyric, iso-valeric, valeric, hexanoic and heptanoic acids, at three dilutions to give individual acid concentrations of 50, 250 and $500 \mathrm{mg} \mathrm{L}^{-1}$, respectively.

Further characterisation was conducted on samples prepared by air drying to constant weight then milling in a micro-hammer mill (Glen Creston Ltd., London, UK) to a particle size $\leq 0.5 \mathrm{~mm}$. Calorific values $(\mathrm{CV})$ of materials were measured by a CAL2k-ECO bomb calorimeter (DDS Calorimeters, 
Gauteng, South Africa). The total organic carbon (TOC) was quantified with a Dohrmann DC-190 High temperature TOC Analyzer (Rosemount Analytical Inc., Irvine, USA). Lipid analysis used a Soxhlet extraction method [46]; lipids are reported as n-hexane extractable material (HEM). Determination of hemi-cellulose, cellulose and lignin was through applying neutral detergent fibre (NDF), acid detergent fibre (ADF) and acid detergent lignin (ADL) methods, using a FiberCap ${ }^{\text {TM }} 2023$ fibre analysis system (Foss, Warrington, UK) [47,48]. Content of non-structural carbohydrates (i.e., starches and sugars) was determined by difference (1000 - weight in grams (lipids + proteins + hemi-cellulose + cellulose + lignin) in $1000 \mathrm{~g}$ VS). The content in biodegradable carbon was determined through calculation, namely by deducting the value for lignin carbon from the TOC value; for lignin, the formula used was $\mathrm{C}_{9} \mathrm{H}_{10.16} \mathrm{O}_{2.82}$ [49]. Elemental composition $(\mathrm{C}, \mathrm{H}, \mathrm{N}, \mathrm{S}, \mathrm{O})$ of the substrate was analysed using a FlashEA 1112 Elemental Analyser (Thermo Finnigan, Rodano, Italy), according to the manufacturer's standard procedures. Inorganic elements were extracted by microwave digestion in nitric acid, using as equipment Model MARS $X^{\mathrm{R}}$, XP-1500 Plus (CEM Corporation, Buckingham, UK), and the filtered extract was diluted to $50 \mathrm{~mL}$ with deionised water (Milli-Q Gradient, Millipore, Watford, UK). Cd, Cr, $\mathrm{Cu}, \mathrm{K}, \mathrm{Ni}, \mathrm{Pb}$, and $\mathrm{Zn}$ concentrations were measured using a flame atomic absorption spectrometer, type Spectr AA-200 (Varian, Palo Alto, USA). The concentration of Hg was identified by cold-vapour atomic fluorescence spectrometry; the equipment was a PSA 10.025 Millennium Merlin unit (PS Analytical Ltd., Kent, UK). To determine the content of phosphorus, the ammonium molybdate spectrometric method (ISO 6878: 2004) was applied.

\section{Results}

\subsection{Methane Yields of Pasteurised and Unpasteurised Substrates}

Figure 1 shows methane production from pasteurised and unpasteurised materials, namely food waste (Figure 1a), cattle slurry (Figure 1b), card packaging (Figure 1c), potato waste (Figure 1d), slaughterhouse waste (Figure 1e), animal blood (Figure 1f) and OFMSW (Figure 1g). Methane production is reported in cubic metres methane at STP per kilogram VS of added substrate (STP $\mathrm{m}^{3}$ $\mathrm{kg}^{-1} \mathrm{VS}$ ), and the experimentally found biochemical methane potential (BMP) is the final methane yield at the end of the testing process. This section presents the experimental results, while Section 3.2 compares the experimental findings with theoretical values.

Looking at the performance of source-separated domestic food waste, Figure 1a shows that methane production from unpasteurised and pasteurised substrate was very similar throughout the digestion experiment. Both materials showed rapid digestion after initiation of the experiment. The methane production rate from unpasteurised food waste was slightly higher during day 2, but the pasteurised material subsequently caught up, which resulted in BMP values that were nearly equal at the end of the testing, namely $0.475 \pm 0.031 \mathrm{STP} \mathrm{m}^{3} \mathrm{~kg}^{-1} \mathrm{VS}$ for unpasteurised and $0.473 \pm 0.026 \mathrm{STP}$ $\mathrm{m}^{3} \mathrm{~kg}^{-1} \mathrm{VS}$ for pasteurised food waste. This difference in the methane yield from unpasteurised and pasteurised food waste is statistically not significant $(p=0.936$ in unpaired, two-tailed Student's $t$-test). Therefore, the hypothesis that pre-pasteurisation increases the methane yield from food waste is to be rejected.

Methane production from cattle slurry (Figure 1b) was very similar for the unpasteurised and the pasteurised material throughout the digestion test, and the obtained BMP values at the end of the testing were also very similar. The BMP value for unpasteurised cattle slurry was $0.267 \pm 0.004$ STP $\mathrm{m}^{3} \cdot \mathrm{kg}^{-1}$ VS and for pasteurised cattle slurry it was $0.269 \pm 0.004 \mathrm{STP} \mathrm{m}^{3} \cdot \mathrm{kg}^{-1} \mathrm{VS}$, and, thus, the difference was statistically not significant $(p=0.929)$.

Unpasteurised and pasteurised card packaging both showed a one-day lag in methane production at the early stage of the test, as can be seen in Figure $1 c$, and closely similar rates thereafter. BMP values were $0.266 \pm 0.010 \mathrm{STP} \mathrm{m}^{3} \mathrm{~kg}^{-1}$ VS for unpasteurised and $0.267 \pm 0.005 \mathrm{STP} \mathrm{m} \mathrm{m}^{3} \cdot \mathrm{kg}^{-1} \mathrm{VS}$ for pasteurised substrate, respectively; this small difference in the measured methane yields of unpasteurised and pasteurised material is statistically not significant $(p=0.884)$. 


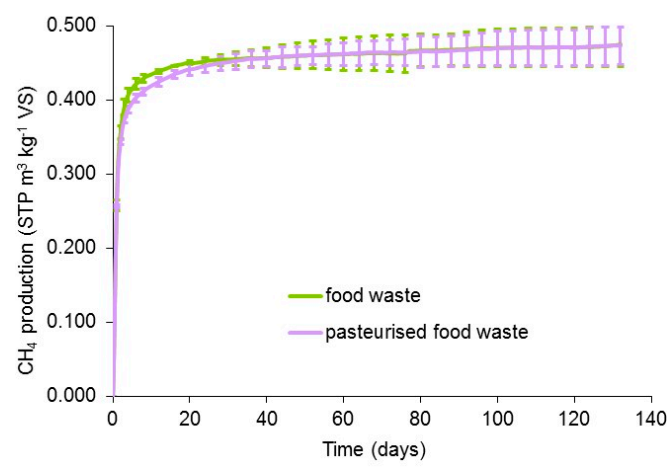

(a)

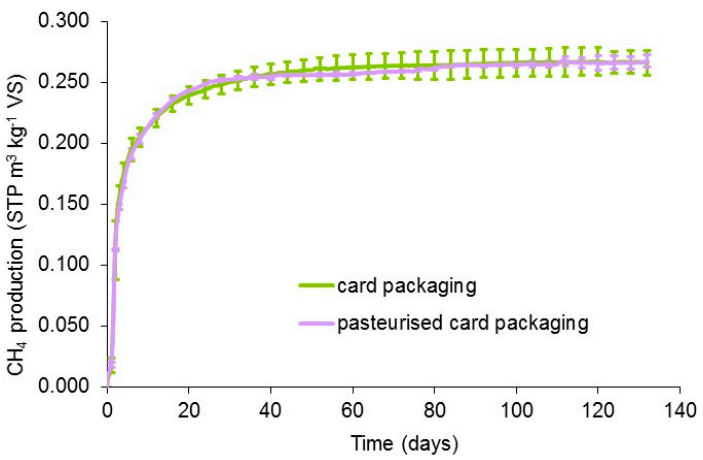

(c)

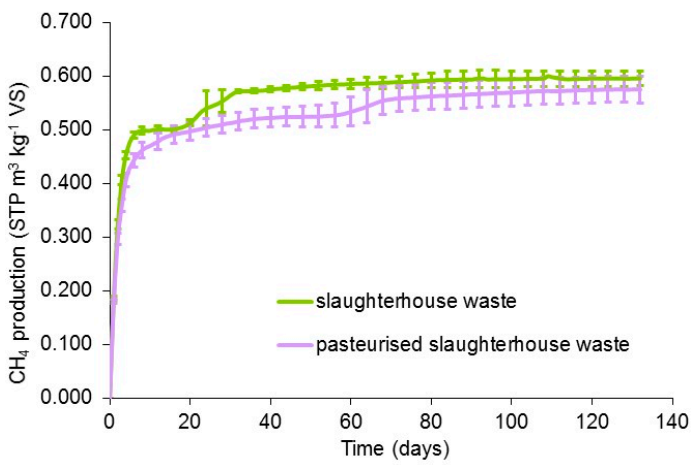

(e)

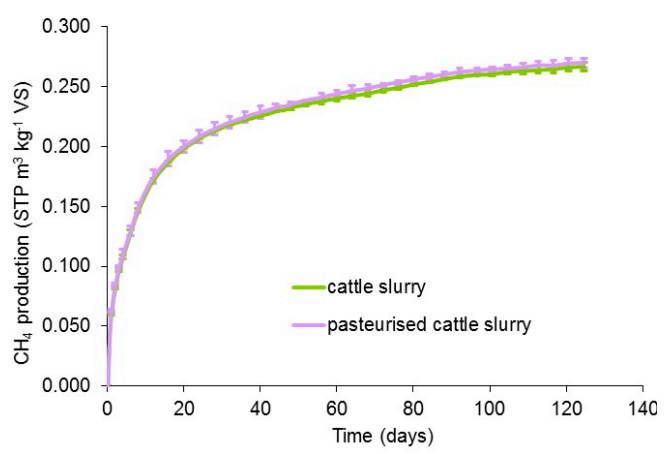

(b)

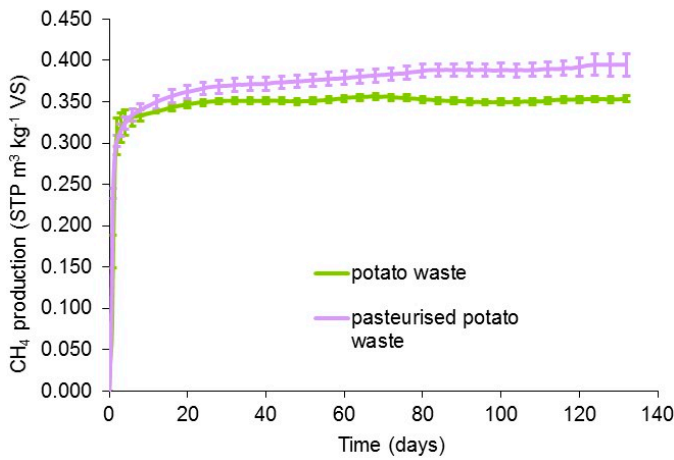

(d)

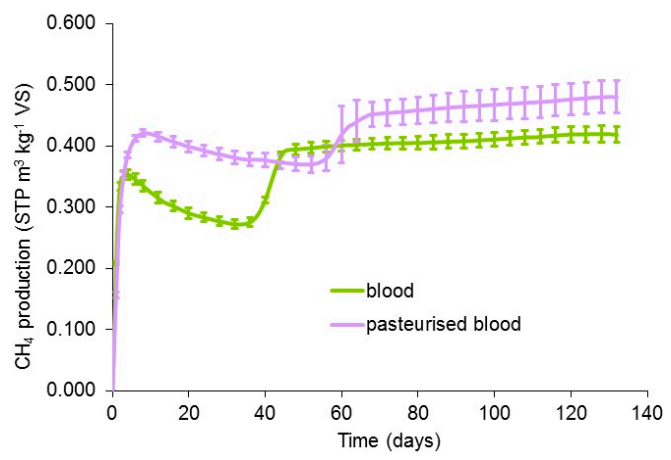

(f)

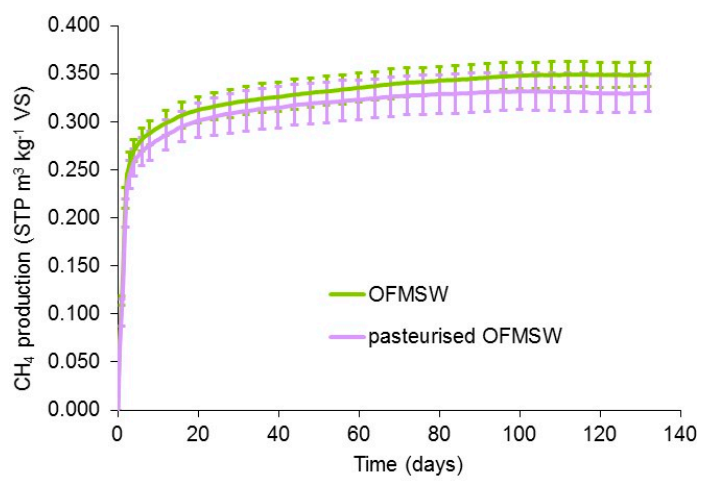

(g)

Figure 1. Methane production of unpasteurised and pasteurised substrates: (a) food waste; (b) cattle slurry; (c) card packaging; (d) potato waste; (e) slaughterhouse waste; (f) animal blood; (g) OFMSW (organic fraction of municipal solid waste). 
Pasteurised potato waste had a slightly higher rate of methane production than unpasteurised during the first days of the test (Figure 1d), but by day 5 the cumulative productions were the same; after this, production flattened in the unpasteurised substrate, while it continued to increase slightly in the pasteurised waste. The BMP value for unpasteurised potato waste was $0.353 \pm 0.004 \mathrm{STP} \mathrm{m} \cdot \mathrm{kg}^{-1}$ VS and for pasteurised potato waste it was $0.395 \pm 0.014 \mathrm{STP} \mathrm{m}^{3} \cdot \mathrm{kg}^{-1} \mathrm{VS}$; this difference in BMP values is statistically significant at both the $95 \%$ confidence level and the $99 \%$ confidence level $(p=0.007)$. This provides strong support to the hypothesis that pre-pasteurisation of potato waste results into higher methane generation from this substrate during the subsequent anaerobic digestion. It should be noted that the potato waste in this study consisted of chip rejected from crisp manufacturing, which contains very little peel; thus, the methane yield was higher than that reported elsewhere for potato peel $\left(<0.300 \mathrm{~m}^{3} \cdot \mathrm{kg}^{-1} \mathrm{VS}\right)[50]$.

The methane production rate from unpasteurised slaughterhouse waste was higher than from pasteurised slaughterhouse waste early in the test period (Figure 1e); however, from day 7 onwards, the unpasteurised test material slowed down its methane generation, while the pasteurised slaughterhouse waste continued to demonstrate increasing methane production. By day 16, both test materials had yielded about the same volume of methane. Subsequently, a short-term increase in the methane production rate occurred for the unpasteurised substrate, which may be attributable to the breakdown of poorly-biodegradable intestinal contents. A short-term increase in methane production rate was also noticed for the pasteurised material at a later stage (day 60); the same explanation may apply. The BMP values were $0.595 \pm 0.014 \mathrm{STP} \mathrm{\textrm {m } ^ { 3 }} \mathrm{kg}^{-1} \mathrm{VS}$ (unpasteurised pig gut with flotation fat) and $0.575 \pm 0.025 \mathrm{STP} \mathrm{m} \mathrm{m}^{3} \cdot \mathrm{kg}^{-1} \mathrm{VS}$ (pasteurised pig gut with flotation fat), respectively. The lower methane yield of the pasteurised slaughterhouse waste compared to the unpasteurised substrate is noticeable in the experimental data, but statistical significance of the difference at the $95 \%$ confidence level is not confirmed $(p=0.293)$, and, thus, the difference must be interpreted as non-significant based on the current data. Clearly, the present work rejects the hypothesis of a higher methane yield from pasteurised slaughterhouse waste compared to the unpasteurised material.

Turning to the AD performance of sheep blood, Figure $1 \mathrm{f}$ shows that the unpasteurised substrate initially had a slightly higher methane production rate compared to the pasteurised substrate; an explanation for this may be the reduced specific surface area that was available for enzymic attack in the pasteurised blood as a result of heat coagulation. From day 4 onward, methane production from test digesters with unpasteurised blood was lower than from the control (inoculum only), leading to the decline in net specific cumulative methane production seen in Figure 1f. A similar decline was seen from day 9 for pasteurised blood, but in both cases, these declines were subsequently reversed. Methane production from the unpasteurised blood rose quickly from day 33. For pasteurised blood, the degree of inhibition initially appeared to be less than in the digesters containing the unpasteurised substrate, but methane generation from the pasteurised blood only began to recover from day 51 . The final BMP values were $0.418 \pm 0.013 \mathrm{STP} \mathrm{m^{3 }} \mathrm{kg}^{-1} \mathrm{VS}$ for unpasteurised blood and $0.479 \pm 0.026 \mathrm{STP}$ $\mathrm{m}^{3} \cdot \mathrm{kg}^{-1}$ VS for pasteurised blood, respectively. This difference in BMP values is statistically significant $(p=0.022)$, which provides evidence that pasteurisation as a pre-treatment has a significant impact on the methane yield of blood.

There is no clear explanation for the above described behaviour of blood during the course of the digestion, i.e., the patterns of inhibition observed, but a high free ammonia concentration in the blood digestion might have contributed to this apparent inhibition; calculations based on the nitrogen content of the material suggested that the TAN concentration in the digestate could reach $2.5 \mathrm{~g} \mathrm{~N} \mathrm{~L}^{-1}$. Strong inhibition of AD due to the high nitrogen content of the substrate has previously been reported in literature for poultry blood waste [51]. Occurrence of elevated levels of propionic acid in the course of the degradation of blood proteins [52,53] might also cause inhibition, but no samples could be taken for measurement of VFA, TAN or $\mathrm{pH}$ to confirm this, since the digesters were sealed in this experiment.

For mechanically recovered OFMSW, the initial methane production rates from unpasteurised and pasteurised material were closely similar, as can be seen in Figure 1g. The unpasteurised substrate 
demonstrated slightly higher methane generation until day 3, but thereafter cumulative production was roughly parallel. BMP values were $0.349 \pm 0.013 \mathrm{STP} \mathrm{m}^{3} \cdot \mathrm{kg}^{-1} \mathrm{VS}$ for unpasteurised OFMSW and $0.330 \pm 0.019 \mathrm{STP} \mathrm{m}^{3} \cdot \mathrm{kg}^{-1} \mathrm{VS}$ for pasteurised OFMSW, respectively. This difference, although noticeable among the experimental runs, is statistically not significant at the $95 \%$ confidence level $(p=0.226)$, and, thus, the findings do not confirm a significant impact of the pasteurisation step on the AD of OFMSW.

These results suggest that, for the materials that were tested in this study, pasteurisation had a positive impact on the methane yields from two substrates only, namely from potato waste and from sheep blood. The pasteurisation pre-treatment had no significant impact on the rate of anaerobic biodegradation or the extent to which the other tested biomasses were degraded, i.e., the obtained BMP values were not significantly different with and without pasteurisation for food waste, cattle slurry, card packaging, slaughterhouse waste and OFMSW. However, for food waste and slaughterhouse waste pasteurisation led to slightly slower digestion at the start of the AD process, which indicates some impact on the kinetics during the early stages of the process, while the final methane values nevertheless were not significantly impacted.

\subsection{Comparison of Experimental and Theoretical Methane Yields}

The comparison of the experimentally found methane yield (BMP values) and the theoretical BMP value of a substrate (determined through calculation using the biochemical composition, see Section 2.4) shows the actual degree of exploitation of the theoretically available potential. Table 2 shows the experimental results and theoretical methane production for the selected unpasteurised and pasteurised co-substrates. It can be seen from the table that the experimental methane yields for all of the substrates apart from cattle slurry were equal to $80 \%$ or more of the theoretical methane yield. These results are discussed in detail in Section 4.1.

Table 2. Comparison of experimental methane yields with the theoretical values calculated based on the biochemical composition.

\begin{tabular}{|c|c|c|c|c|c|}
\hline \multirow[b]{2}{*}{ Substrate } & \multirow{2}{*}{$\begin{array}{c}\text { Theoretical BMP } \\
\text { Value (STP } \\
\mathrm{m}^{3} \cdot \mathrm{kg}^{-1} \text { VS) }\end{array}$} & \multicolumn{2}{|c|}{ Unpasteurised } & \multicolumn{2}{|c|}{ Pasteurised } \\
\hline & & $\begin{array}{l}\text { Experimental BMP Value } \\
\left(\mathrm{STP} \mathrm{m}^{3} \mathrm{~kg}^{-1} \mathrm{VS}\right)\end{array}$ & $\begin{array}{l}\text { Ratio of Experimental to } \\
\text { Theoretical Value (\%) }\end{array}$ & $\begin{array}{l}\text { Experimental BMP Value } \\
\left(\mathrm{STP}^{3} \cdot \mathrm{kg}^{-1} \mathrm{VS}\right)\end{array}$ & $\begin{array}{l}\text { Ratio of Experimental to } \\
\text { Theoretical Value (\%) }\end{array}$ \\
\hline Food waste & 0.507 & $0.475 \pm 0.031$ & 93.7 & $0.473 \pm 0.026$ & 93.3 \\
\hline Cattle slurry & 0.393 & $0.267 \pm 0.031$ & 67.9 & $0.269 \pm 0.019$ & 68.4 \\
\hline Card packaging & 0.327 & $0.266 \pm 0.010$ & 81.3 & $0.267 \pm 0.005$ & 81.7 \\
\hline Potato waste & 0.407 & $0.353 \pm 0.004$ & 86.7 & $0.395 \pm 0.014$ & 97.1 \\
\hline Slaughterhouse waste & 0.659 & $0.595 \pm 0.014$ & 90.3 & $0.575 \pm 0.025$ & 87.3 \\
\hline Animal blood & 0.498 & $0.418 \pm 0.013$ & 83.9 & $0.479 \pm 0.026$ & 96.2 \\
\hline OFMSW & 0.384 & $0.349 \pm 0.013$ & 90.9 & $0.330 \pm 0.019$ & 86.0 \\
\hline
\end{tabular}

BMP: biochemical methane potential; STP $\mathrm{m}^{3} \mathrm{~kg}^{-1} \mathrm{VS}$ : cubic metres at standard temperature and pressure per kilogram volatile solids.

Methane values were also expressed on a wet weight basis (i.e., weight of fresh material) to take into account the moisture content and inert fraction of the substrates (Table 1), and the results are shown in Table 3. Of the materials tested, card packaging had the highest methane yield due to its very low moisture (6\%) and low inert fraction (only 16\% of TS). Food waste and OFMSW had comparable methane potentials. The very low methane yield of cattle slurry (less than $10 \%$ of that of card packaging on a wet weight basis) makes it unattractive as a sole substrate for energy production and also confirms the suitability of high-solids, high-methane feedstocks such as food waste as co-substrates, since these can give a significant boost to methane production [34]. 
Table 3. Methane yields of unpasteurised and pasteurised wastes on a fresh matter basis, i.e., per unit of wet weight (WW).

\begin{tabular}{ccc}
\hline Substrate & $\begin{array}{c}\text { BMP Unpasteurised Material } \\
\text { (STP } \mathbf{~ m}^{\mathbf{3}} \cdot \text { tonne }^{-\mathbf{1}} \mathbf{W W )}\end{array}$ & $\begin{array}{c}\text { BMP Pasteurised Material (STP } \\
\mathbf{m}^{\mathbf{3}} \cdot \text { tonne }^{\mathbf{- 1}} \mathbf{W W} \text { ) }\end{array}$ \\
\hline Food waste & 102 & 102 \\
Cattle slurry & 17.4 & 17.5 \\
Card packaging & 210 & 211 \\
Potato waste & 81.5 & 91.2 \\
Slaughterhouse waste & 115 & 112 \\
Animal blood & 79.0 & 90.5 \\
OFMSW & 114 & 108 \\
\hline
\end{tabular}

\subsection{Effect of Co-Pasteurisation of Food Waste and Cattle Slurry}

Food waste and cattle slurry as co-substrates in AD, mixed at a ratio of 20:80\% (VS basis), were tested after both separate pasteurisation (i.e., food waste and cattle slurry pasteurised separately and then mixed for digestion) and co-pasteurisation (i.e., food waste and cattle slurry mixed before pasteurisation, then pasteurised as mixture and then digested). From Figure 2, it can be seen that the performance (BMP and rate of methane production) of food waste and cattle slurry pasteurised separately and then mixed was closely similar to the performance of the co-pasteurised mixture. The results were also compared with predicted values based on the methane production from food waste and cattle slurry as individual substrates, which is also shown in Figure 2. The pro rata sum of the BMP values for the two components when pasteurised and tested individually was $0.310 \pm 0.006 \mathrm{STP} \mathrm{m} \mathrm{kg}^{-1} \mathrm{VS}$. When they were pasteurised individually but tested as a mixture,

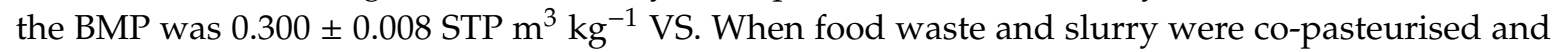

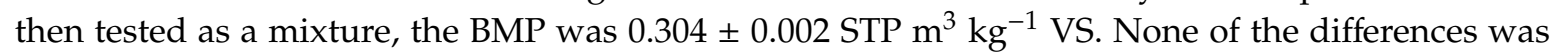
statistically significant ( $p>0.05$ in all cases). There was thus no clear synergistic or antagonistic effect from either co-pasteurisation or co-digestion, i.e., methane generation was not impacted by whether substrates were first mixed and then pasteurised or were pasteurised individually and then mixed before digestion.

\subsection{Profiles of VFA and Ammonia in Digestion of Pasteurised and Unpasteurised Food Waste}

As can be noticed when looking at Figure 3a, total VFA concentrations in both unpasteurised and pasteurised domestic food waste increased to a level of close to $550 \mathrm{mg} \mathrm{VFA} \mathrm{L}^{-1}$ (this corresponds to $720 \mathrm{mg} \mathrm{COD} \mathrm{L}^{-1}$ ) during the first $12 \mathrm{~h}$ of digestion, but then fell rapidly to $<100 \mathrm{mg} \mathrm{VFA} \mathrm{L}^{-1}$ within less than two days. This points out that the inoculum contained a well-balanced microbial population capable of regulating any effects of differential reaction rates that may occur at early stages of a BMP test, and there was no accumulation of potentially inhibitory intermediate products in the digesters. As revealed by the VFA profile in Figure 3b, during the short-lived peak in total VFA, acetic acid on a mass basis made up approximately $55 \%$ of the total VFA concentration (this corresponds to $46 \%$ on a COD basis), with propionic acid contributing approximately $30 \%$ to total VFA on a mass basis (this corresponds to $26 \%$ on a COD basis). The third-largest component of total VFA was iso-valeric acid, followed by n-butyric and iso-butyric acid. No significant difference was found between the VFA profiles of the pasteurised and unpasteurised food waste. 


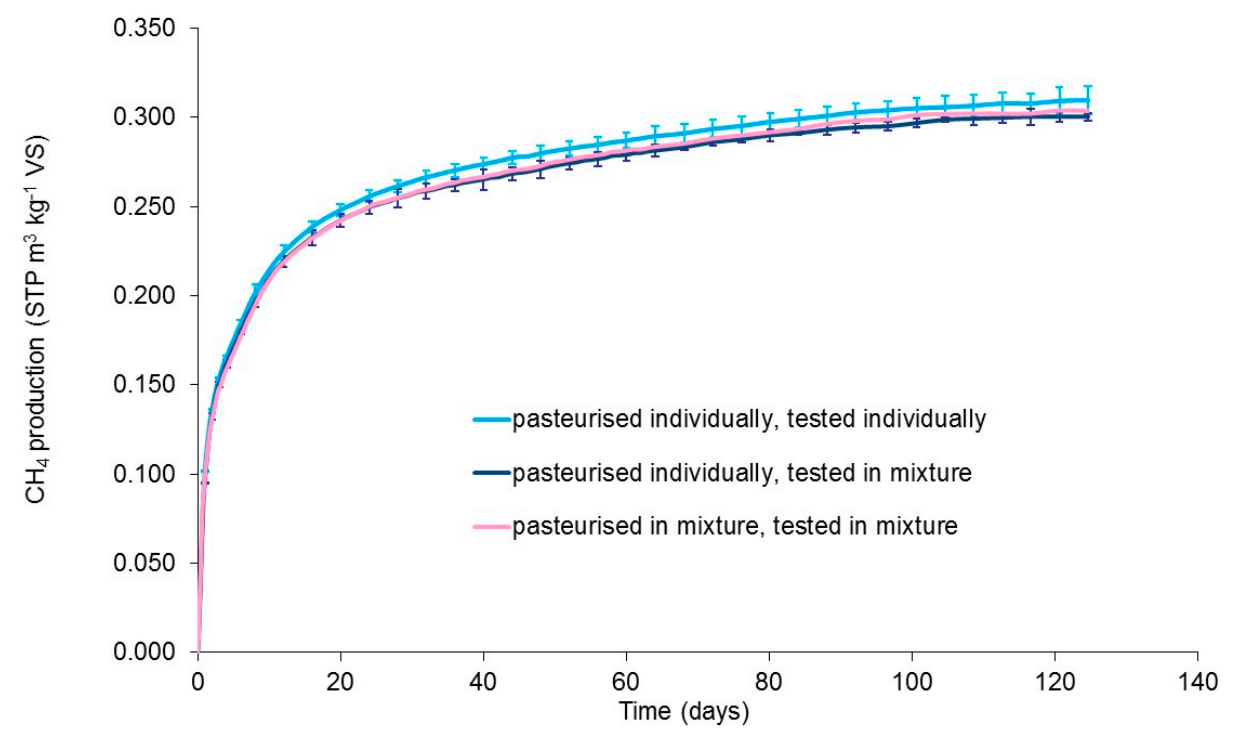

Figure 2. Methane production assay to study the impact of co-pasteurising two substrates (food waste and cattle slurry) before their digestion (showing the methane yield of the co-pasteurised mixture, the methane yield of the mixture blended from the individually pasteurised substrates and the calculated values for the combined methane production from pasteurised food waste and pasteurised cattle slurry obtained by summing daily values for each component; note: no standard deviations shown for "pasteurised in mixture, tested in mixture" to improve readability of figure).

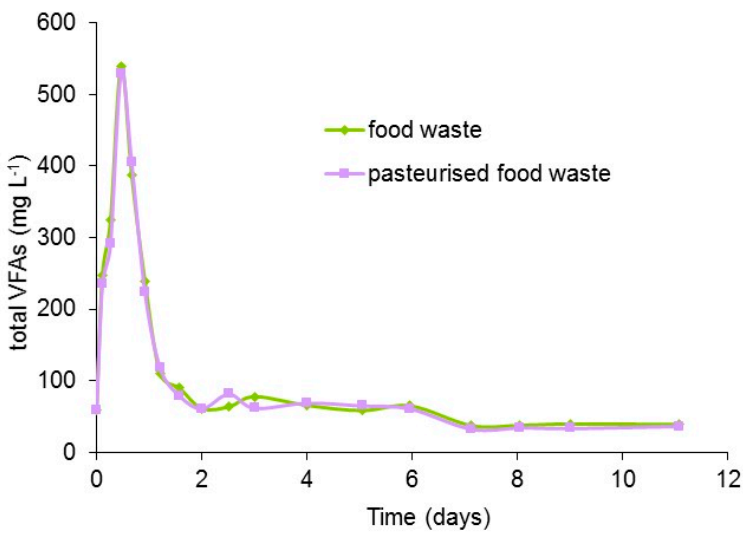

(a)

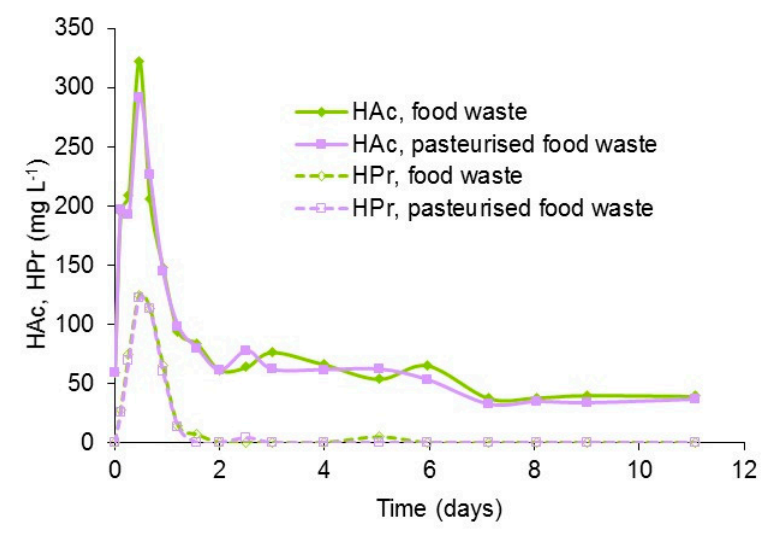

(b)

Figure 3. Volatile fatty acid (VFA) profiles in unpasteurised and pasteurised food waste during AD: (a) total VFA; (b) acetic acid (HAc) and propionic acid (HPr).

TAN concentration in the digesters was also monitored, and a gradual increase from around $1.5 \mathrm{~g} \mathrm{~N} \mathrm{~L}^{-1}$ (contributed by the inoculum) to $2.0 \mathrm{~g} \mathrm{~N} \mathrm{~L}^{-1}$ during the first 30 days of operation was observed. The TKN entering the reactors with the feedstock (pasteurised and unpasteurised food waste) was only around $0.24 \mathrm{mg} \mathrm{N} \mathrm{L}^{-1}$. The profile of TAN concentration in the inoculum control was not monitored due to limitations on the number of test digesters available; thus, it was not possible to carry out a complete mass balance. It can be assumed, however, that some of the TAN seen in the course of the digestion was contributed by the inoculum. 


\section{Discussion}

\subsection{Discussion of the Results from the Digestion Experiments with Pasteurised and Unpasteurised Substrates}

Of the materials tested in this study, pre-pasteurisation at $70^{\circ} \mathrm{C}$ before $\mathrm{AD}$ only showed a positive impact on the methane yield for potato waste and sheep blood.

With potato waste, the experimental BMP reached $97 \%$ of the theoretical value with the pasteurised material, but only $87 \%$ with the unpasteurised substrate. It is interesting to note that methane production for the unpasteurised potato waste ceased after few weeks, but continued for the pasteurised waste, albeit at a low rate. This suggests that pasteurisation affected the physical structure of the substrate, enabling microorganisms to access areas which were otherwise difficult to reach. Improving microbial access to lignified biomass is frequently given as the aim of pre-treatment of AD feedstocks, and is commonly attempted because potentially degradable substances are shielded in lignocellulosic material [54]. Such an explanation cannot apply in this case, however, as the potato waste used in this study consisted of chips rejected from crisp manufacturing, no significant quantities of peel were present, and, thus, the lignin content of the material was relatively low (Table 1). A possible explanation for the better performance of pasteurised potato waste is the heat-induced gelatinisation process during pasteurisation, which may have altered the structure of starch granules and made the content more accessible. Gelatinisation occurs when starch granules are heated in water, because the granules absorb large amounts of water and finally burst, thus releasing the starch molecules [55]. Several authors have documented that heat-treated potato is more readily biodegradable by rumen microbiota [56-58]. Gelatinisation of starches during heat application can be affected by the presence of other constituents [55,59], and thus might not necessarily occur with other starch-containing substrates, especially if these are more balanced at the physicochemical level. The potato waste had an exceptionally high share of non-structural carbohydrates (starch), amounting to 83\% of the total VS, while it was very low in structural carbohydrates (hemi-cellulose, cellulose) and lignin, and low in proteins. The type of starch and composition of the substrate also influence the temperature at which gelatinisation occurs. For potato, a relatively low gelatinisation onset temperature of $58.2^{\circ} \mathrm{C}$ and a gelatinisation peak at $62.6^{\circ} \mathrm{C}$ were reported in literature, i.e., well below the pasteurisation temperature of $70{ }^{\circ} \mathrm{C}$ applied in this work; however, for materials such as different wheat types, green banana or rice, temperatures above $70{ }^{\circ} \mathrm{C}$ were required for gelatinisation [60].

For the substrates with higher lignin content (cattle slurry, OFMSW, card packaging), pasteurisation did not increase the methane yield during testing. Card packaging yielded around $81 \%$ of its theoretical methane potential both with and without pasteurisation (Table 2). Unpasteurised cattle slurry yielded $68 \%$ of the theoretical potential, and OFMSW 91\%; however, pasteurisation did not improve the experimental methane yield for these substrates. This was also found for cattle slurry by Liu et al. [12] and for OFMSW by Grim et al. [10], and the results of this work thus support these observations-although it should be mentioned that for cattle slurry, the literature is not fully consistent since an increase in methane yield after pasteurisation has also been reported in some cases $[1,16]$. A possible explanation for these differing findings might be that manure can be subject to long storage on the farm, which will impact the characteristics of its constituents [12]. From the observations made in this study, it can be concluded that pasteurisation at $70^{\circ} \mathrm{C}$ for $1 \mathrm{~h}$ did not improve biodegradability of materials which were rich in lignin.

For OFMSW, the unpasteurised material yielded $91 \%$ of the theoretical methane potential, but the pasteurised material 5 percentage points less, namely 86\% (Table 2). Grim et al. [10] also observed a lower methane yield for pasteurised OFMSW compared to unpasteurised, although the difference was very small and statistically not significant; the results are difficult to compare directly as Grim, et, al . used a continuous AD process, but this also showed no positive effects of pasteurisation on biogas production from OFMSW. In the present research, which used batch AD tests, it was observed that methane production from unpasteurised substrate was higher during the first three days of digestion, while methane production from unpasteurised and pasteurised OFMSW proceeded in 
parallel afterwards (Section 3.1). This suggests that for OFMSW, pasteurisation did not increase enzymatic accessibility to organic compounds for microorganisms. It further suggests that during the first three days, a smaller amount of readily degradable material was available in the pasteurised biomass compared to the unpasteurised. An explanation for this might be a partial loss of volatile substances such as alcohols at the pasteurisation temperature of $70^{\circ} \mathrm{C}$. OFMSW is the result of a series of collection, storage, separation and mechanical pre-treatment steps, and some microbial activity such as hydrolysis and acidification with production of volatile substances will usually occur before the material reaches the AD plant. Wilkins [61] identified 90 volatile organic compounds which evaporated from stored household waste at ambient temperature, and gaseous emission of volatile compounds increases at higher temperatures. Emission of volatile compounds is also common for food waste which has undergone a period of storage, and such emission increases at raised temperatures [62].

The phenomenon outlined for OFMSW might also explain why, compared to the unpasteurised material, methane production from pasteurised food waste and slaughterhouse waste was lower during the first days of digestion (see Figure 1); the final methane yield was also observed to be lower (Table 2) but the difference in methane yield from unpasteurised and pasteurised substrate was not confirmed to be statistically significant (see Section 3.1). While statistical testing classified the difference in the final methane yield from pasteurised and unpasteurised material as being nonsignificant at $95 \%$ confidence based on the available data, the lower methane generation, which is noticeable for the pasteurised material in the data of the experimental runs for OFMSW, food waste and slaughterhouse waste, suggests that this phenomenon of a reduced methane yield after pasteurisation should be studied in more detail. It can tentatively be concluded that for substrates which contain easily degradable components and undergo periods of storage or other steps where microbial degradation can generate volatile organic compounds, pasteurisation prior to $\mathrm{AD}$ may cause a reduction of methane yield due to loss of volatile compounds at the elevated pasteurisation temperature. More research is required to verify this explanation and to quantify this phenomenon.

The experimental BMP value of unpasteurised food waste reached $94 \%$ of its theoretical BMP value (see Table 2), i.e., nearly the full theoretical potential was exploited. This suggests pre-treatment of food waste to increase its specific methane yield is probably a waste of effort. Pasteurisation is still required for hygienisation purposes, but it is not an effective strategy to increase methane yield. When poor performance in $\mathrm{AD}$ of food waste is encountered, monitoring of trace elements and choice of adequate loading of the reactor are usually effective strategies to overcome this [63], while pre-treatment of the substrate is not a promising approach.

Pasteurisation had a significant effect on the reaction kinetics of blood during the digestion but attributing this effect to one particular aspect of the heat treatment is difficult because the reason for the observed inhibition is not clear. The slightly slower methane generation from pasteurised blood in the first $72 \mathrm{~h}$ may have been due to the lower specific surface area initially available for enzymic attack as a result of heat coagulation. From day 4 to 35, however, digestion of the unpasteurised sheep blood, when compared to the pasteurised blood, seems to have experienced more severe inhibition by intermediate (e.g., VFA) and/or final (e.g., ammonia) digestion products. This effect might be mastered if an even higher i/s ratio was adopted (i.e., a more elevated ratio of inoculum to substrate to further reduce the likelihood of process inhibition) or if an inoculum better acclimated to the digestion of blood was chosen. The inhibition seen in this test makes it difficult to interpret the results for blood in detail. Two findings are evident, however, namely, the high risk of process inhibition and the significantly increased final methane yield after pasteurisation. While unpasteurised blood yielded $84 \%$ of the theoretical methane potential, pasteurised blood reached $96 \%$ of the theoretical value (Table 2). Of all materials tested, blood had the highest content in protein and the lowest content in carbohydrates (Table 1). The high nitrogen content is likely to have caused ammonia inhibition during AD, but it is interesting to note that the pasteurised material was initially less affected by inhibition then required longer to recover, and at the same time the final methane yield was significantly increased. An increase in methane yield for pasteurised slaughterhouse waste rich in blood was previously reported in the 
literature [18], but blood itself has not received much attention thus far. From this research, it can be concluded that pasteurisation ultimately increased the methane yield from blood, but it also slowed the recovery process after inhibition. It requires further study to fully understand the nature of the different impacts observed for the processing of blood and to explore whether the observed phenomena also occur in continuous $\mathrm{AD}$ operation.

It is evident that pasteurisation had a very differing impact on animal blood and slaughterhouse waste, which in this study was composed of pig gut and flotation fat. The slaughterhouse waste was rich in lipids and proteins, while the blood was very rich in proteins but very poor in carbohydrates (Table 1). An increased methane yield was found only for blood, while pasteurisation altered AD kinetics for both blood and slaughterhouse waste, but with very different patterns (Figure 1). Digestion of pasteurised slaughterhouse proceeded more slowly than digestion of unpasteurised slaughterhouse waste. Similar observations were reported for slaughterhouse waste by Hejnfeld and Angelidaki [19], Luste et al. [20] and Ware and Power [8], but observations which contradict this are also documented [12]. Different experimental procedures might explain such contradictions [1]. The findings of this work suggest, however, that the composition of different slaughterhouse wastes has a major role in explaining such contradictory observations. Some slaughterhouse wastes might be composed mainly of fatty fractions, while other wastes might contain high proportions of blood and hair. The results of this study show that the AD-relevant impact of pasteurisation on blood is very different from the impact on other types of animal by-products. The results also agree with observations made by Rodriguez-Abalde et al. [21], who found a lowered bioavailability after pasteurisation of slaughterhouse waste rich in carbohydrates (including hemi-cellulose and cellulose as structural carbohydrates), but an increased methane yield for a slaughterhouse waste with low carbohydrate concentration.

\subsection{Discussion of the Testing Procedure}

In BMP testing, a high $\mathrm{i} / \mathrm{s}$ ratio is applied (in this study, the ratio on a VS basis was 4:1) to arrange for a robust microbial consortium and "buffer" the differential rates of microbially mediated reactions when starting a batch AD test [64]. Methane generation typically begins with little or no lag; then, after some time, the methane production rate gradually tails off. If the $\mathrm{i} / \mathrm{s}$ ratio is too low, this response changes, however, as the rapid onset of fermentation by acid-forming bacteria outpaces the capacity of the methanogenic population to deal with the resulting intermediate products. This can lead to the development of acidic conditions, typically reflected by a dip in the methane generation curve. Time is then required for the slower-growing methanogens to "catch up", and thus for the whole AD process to recover. Where the initial $\mathrm{i} / \mathrm{s}$ ratio is strongly unfavourable, or the feedstock is particularly rich in rapidly degradable components, the $\mathrm{pH}$ can fall to such a low point that methane production cannot occur. With food waste, characterised by an elevated content of readily fermentable components, some initial imbalance of the AD process is most likely even at a favourable i/s ratio, but does not necessarily inhibit methanogenesis. In the current work, the accumulation of VFA (Figure 3a) did not prevent the onset of methane production (Figure 1a), and the initial VFA peak was rapidly transformed into biogas within less than two days. Monitoring of VFA profiles is not an integral part of the BMP testing but was accomplished in this work to elucidate any irregularities that might occur in gas production; in this case, no explanation was required, as the BMP curves showed very typical responses.

While the BMP testing provides valuable insights into methane production patterns and ultimate methane yields, the lack of testing for standard parameters such as $\mathrm{pH}$ or for intermediate substances such as VFA and ammonia, which typically change during digestion and can impact process stability, can be a major shortcoming in interpreting the kinetics of the digestion process. In addition, commercial AD plants are usually operated in continuous mode, and the buffered BMP batch test is insufficient to predict the effect of complex interactions in such conditions [65]. While BMP tests alone might not be enough to clarify all aspects of AD performance in practice, however, the high level of standardisation when testing a large number of substrates, quality assurance through the use of controls and replicates, and the potential for ensuring reproducibility of findings make the testing 
procedure useful. The contradictions found in the literature about the impact of pasteurisation on biogas production are at least partially due to differing methods applied, low transparency regarding the procedures and missing quality assurance $[1,8]$. This emphasizes the importance of transparent and quality-controlled procedures, and confirms the need for caution when interpreting observations.

\section{Conclusions}

This work analysed for a range of common waste types under standardised conditions whether pre-pasteurisation at $70{ }^{\circ} \mathrm{C}$ impacted their methane yield in the biogas process.

Among the substrates under study, only potato waste and animal blood showed higher methane yields after pasteurisation, namely an increase in methane yield of $12 \%$ for potato waste and of $15 \%$ for animal blood. After pasteurisation, both materials achieved an experimental BMP value which was more than $95 \%$ of the theoretical BMP, which indicates that in the pasteurised material, the biodegradable constituents were nearly completely available for their conversion into biogas. For potato waste, the positive impact of pasteurisation may be explained by the occurrence of gelatinisation during pasteurisation, when heating causes starch molecules to be released into the liquid phase. Animal blood showed an unusual digestion pattern, and no clear explanation was found in this work for the unstable behaviour of this material during the digestion process, but as an outcome, the methane yield of the pasteurised blood was significantly higher compared to the unpasteurised blood.

Pasteurisation of food waste, cattle slurry and card packaging had no significant impact on methane yield during anaerobic digestion. It is interesting to note that food waste yielded $93-94 \%$ of its theoretical methane potential with and without pasteurisation, thus, high exploitation of the biogas potential of this material can be achieved regardless of whether thermal pre-treatment is applied or not, and, consequently, pre-treatment is anyway not a promising approach to achieve more value from this substrate in $\mathrm{AD}$ (pasteurisation is still required for hygienisation purposes). For cattle slurry and card packaging, the experimental BMP was remarkably lower than the theoretical value, but pasteurisation was not effective to increase the methane yield. Co-digestion with food waste did not improve methane yield from cattle slurry. Furthermore, it made no difference to the methane yield if cattle slurry was pasteurised individually and then co-digested with food waste, or the substrates were co-pasteurised as a mixture before batch digestion.

None of the substrates with a high content of lignified constituents (cattle slurry, card packaging, OFMSW) benefited from pasteurisation with respect to the methane yield achieved. Methane generation from cattle slurry and card packaging was not noticeably impacted by pre-pasteurisation. With OFMSW, the pasteurised material in this study yielded less methane than the unpasteurised substrate, i.e., pasteurisation had a negative impact on the produced methane quantity in the experiments of this study, but statistical testing found the difference nonsignificant at the $95 \%$ confidence level, and, thus, there is insufficient evidence to conclude that a lower methane yield is to be expected for OFMSW due to pre-pasteurisation. A lower methane generation of the pasteurised material was also observed with slaughterhouse waste in this work, but also here, the difference between unpasteurised and pasteurised material was not confirmed to be statistically significant. The observations suggest that for substrates that contain easily degradable components and undergo periods of storage or other steps in which microbial degradation can release volatile organic compounds, the elevated pasteurisation temperature may cause a reduction of methane yield, but more research is required to confirm this hypothesis and to quantify this effect.

Overall, this study shows that pasteurisation before $\mathrm{AD}$ results into higher methane yields during AD only for some specific substrates such as potatoes and blood, while biogas production from lignified biomass is not likely to be increased through pre-pasteurisation; there might also be a risk of a reduced biogas yield from substrates with elevated contents of volatile organic compounds because these can get lost during the thermal pre-treatment. The identification of any common characteristics of those substrates which are positively impacted by pre-pasteurisation requires more research, but this study confirms earlier observations that a low content of structural carbohydrates in combination with 
a high content of other constituents may play a role. Potato waste and animal blood both had a low content of structural carbohydrates (hemi-cellulose, cellulose) but a particularly high content of either non-structural carbohydrates such as starch (potato waste) or proteins (blood).

Whilst the Animal By-products Regulations impose a requirement to pasteurise waste streams which contain animal by-products $(\mathrm{ABP})$ or have been in contact with such materials, the findings of this study indicate that for most substrates pre-pasteurisation before feeding to a biogas plant is unlikely to enhance the efficiency of the anaerobic digestion process itself. This study therefore shows that pre-pasteurisation is not generally an effective strategy for the purpose of increasing the methane generation of a biogas plant and for improving the energy balance of the AD facility.

Supplementary Materials: Data supporting this study are openly available from the University of Southampton repository at https://doi.org/10.5258/SOTON/D1603.

Author Contributions: Conceptualisations, C.J.B. and Y.Z.; methodology, Y.Z., C.J.B. and S.H.; formal analysis, Y.Z., S.H. and S.K.-B.; investigation, Y.Z.; resources, C.J.B. and S.H.; data curation, Y.Z.; writing-original draft preparation, Y.Z., S.H. and S.K.-B.; writing—review and editing, Y.Z., S.K.-B., S.H. and C.J.B.; visualization, Y.Z. and S.K.-B.; supervision, C.J.B. and S.H.; project administration, Y.Z. and C.J.B.; funding acquisition, C.J.B. and S.H. All authors have read and agreed to the published version of the manuscript.

Funding: This research received funding from the Department for Environment, Food and Rural Affairs, London, UK (Defra) under contract WR0212, which is gratefully acknowledged.

Conflicts of Interest: The authors declare no conflict of interest. The funder had no role in the design of the study; in the collection, analyses, or interpretation of data; in the writing of the manuscript, or in the decision to publish the results.

\section{Appendix A. BMP Test on Cellulose Standard (Quality Control)}

Anaerobic digestion of high purity cellulose powder (see Section 2.3) served as quality control for the reliability of the test method applied, as described in the technical report for this project [37], and presented in the following. As can be seen in Figure A1, at the beginning of the test there was a lag of approximately 3 days before methane production from cellulose commenced. This lag period probably reflected the time needed to initiate hydrolysis of the complex macromolecular control material. Methane generation was then rapid, amounting to a cumulative total of $0.361 \pm 0.007 \mathrm{STP} \mathrm{m}^{3}$ $\mathrm{kg}^{-1} \mathrm{VS}$ after the first 16 days, equivalent to $87.0 \%$ of the theoretical BMP of $0.415 \mathrm{STP} \mathrm{m} \mathrm{kg}^{-1} \mathrm{VS}$ Methane generation continued after day 16, but at a considerably lower rate. On day 64, the methane yield was $0.399 \pm 0.007 \mathrm{STP} \mathrm{m} \mathrm{kg}^{-1} \mathrm{VS}$; this corresponds to $96.1 \%$ of the theoretical BMP. The resulting final experimental BMP value for the digested cellulose was $0.409 \pm 0.006 \mathrm{STP} \mathrm{m} \mathrm{kg}^{-1} \mathrm{VS}$, or $98.6 \%$ of the theoretical BMP. This very close agreement between the experimental and theoretical values of the reference material supports the validity of the BMP test method used.

To obtain data on possible losses through dissolution, carbon dioxide production was also recorded in this assay. In Figure A1, it can be seen that the trend in carbon dioxide production was similar to that for methane, with a final yield of $0.406 \pm 0.017 \mathrm{STP} \mathrm{m} \mathrm{CO}_{2} \mathrm{~kg}^{-1} \mathrm{VS}$. This experimental value is equal to $98.0 \%$ of the theoretical specific $\mathrm{CO}_{2}$ production of $0.415 \mathrm{STP} \mathrm{m} \mathrm{CO}_{2} \mathrm{~kg}^{-1} \mathrm{VS}$, indicating that in this case, the use of the acidified saline barrier solution was effective in minimising losses of both gases. 


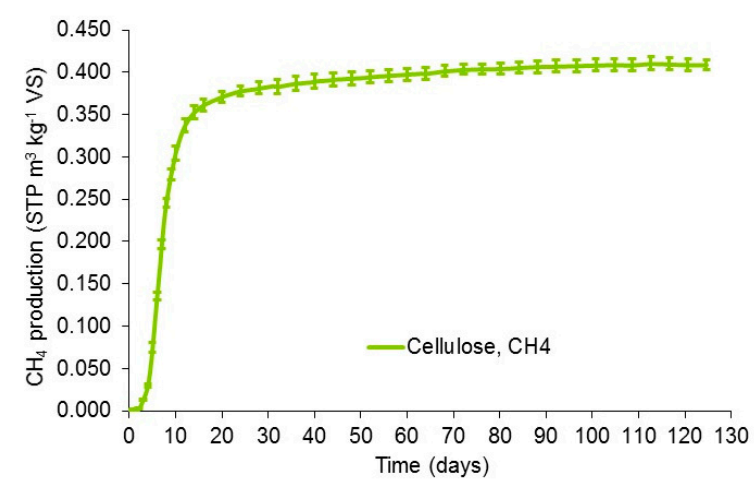

(a)

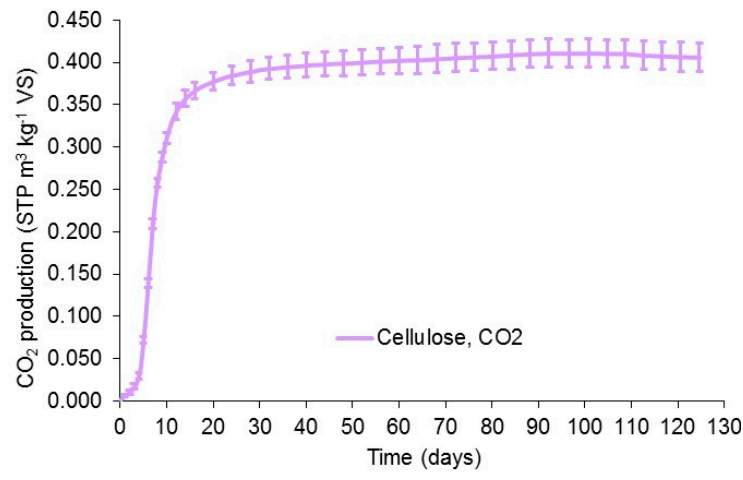

(b)

Figure A1. BMP assay of cellulose as positive control: (a) methane production; (b) carbon dioxide production.

\section{References}

1. Liu, X.; Lendormi, T.; Lanoisellé, J.-L. Overview of hygienization pretreatment for pasteurization and methane potential enhancement of biowaste: Challenges, state of the art and alternative technologies. J. Clean. Prod. 2019, 236, 117525. [CrossRef]

2. Nag, R.; Whyte, P.; Markey, B.K.; O’Flaherty, V.; Bolton, D.; Fenton, O.; Richards, K.G.; Cummins, E. Ranking hazards pertaining to human health concerns from land application of anaerobic digestate. Sci. Total Environ. 2020, 710, 136297. [CrossRef] [PubMed]

3. Nag, R.; Auer, A.; Markey, B.K.; Whyte, P.; Nolan, S.; O’Flaherty, V.; Russell, L.; Bolton, D.; Fenton, O.; Richards, K.; et al. Anaerobic digestion of agricultural manure and biomass-Critical indicators of risk and knowledge gaps. Sci. Total Environ. 2019, 690, 460-479. [CrossRef] [PubMed]

4. Zhao, Q.; Liu, Y. Is anaerobic digestion a reliable barrier for deactivation of pathogens in biosludge? Sci. Total Environ. 2019, 668, 893-902. [CrossRef] [PubMed]

5. Tampio, E. Utilization of Food Waste via Anaerobic Digestion: From Feedstock to Biogas and Fertilizers; Tampere University of Technology Publications: Tampere, Finland, 2016; Volume 1405.

6. EU ABP Regulation 1774/2002. Regulation (EC) No 1774/2002 of the European Parliament and of the Council of 3 October 2002 Laying Down Health Rules Concerning Animal by-Products not Intended for Human Consumption; European Commission: Brussels, Belgium, 2002; Available online: https:/op.europa.eu/en/publication-detail/ -/publication/28ab554e-8e93-4976-89a9-8b6c9d17dfb4 (accessed on 9 March 2020).

7. EU ABP Regulation 1069/2009. Regulation (EC) No 1069/2009 of the European Parliament and of the Council of 21 October 2009 Laying down Health Rules as Regards Animal by-Products and Derived Products not Intended for Human Consumption and Repealing Regulation (EC) No 1774/2002 (Animal by-Products Regulation); European Commission: Brussels, Belgium, 2009; Available online: https://eur-lex.europa.eu/legal-content/EN/ALL/ ?uri=CELEX\%3A32009R1069 (accessed on 9 March 2020).

8. Ware, A.; Power, N. What is the effect of mandatory pasteurisation on the biogas transformation of solid slaughterhouse wastes? Waste Manage. 2016, 48, 503-512. [CrossRef] [PubMed]

9. Luste, S.; Luostarinen, S. Anaerobic co-digestion of meat-processing by-products and sewage sludge-Effect of hygienization and organic loading rate. Bioresour. Technol. 2010, 101, 2657-2664. [CrossRef] [PubMed]

10. Grim, J.; Malmros, P.; Schnürer, A.; Nordberg, A. Comparison of pasteurization and integrated thermophilic sanitation at a full-scale biogas plant - heat demand and biogas production. Energy 2015, 79, 419-427. [CrossRef]

11. Nazari, L.; Yuan, Z.; Santoro, D.; Sarathy, S.; Ho, D.; Batstone, D.; Xu, C.; Ray, M.B. Low-temperature thermal pre-treatment of municipal wastewater sludge: Process optimization and effects on solubilization and anaerobic degradation. Water Res. 2017, 113, 111-123. [CrossRef] 
12. Liu, X.; Souli, I.; Chamaa, M.-A.; Lendormi, T.; Sabourin, C.; Lemée, Y.; Boy, V.; Chaira, N.; Ferchichi, A.; Morançais, P.; et al. Effect of thermal pretreatment at $70{ }^{\circ} \mathrm{C}$ for one hour (EU hygienization conditions) of various organic wastes on methane production under mesophilic anaerobic digestion. AIMS Environ. Sci. 2018, 5, 117-129. [CrossRef]

13. Anukam, A.; Mohammadi, A.; Naqvi, M.; Granström, K. A review of the chemistry of anaerobic digestion: Methods of accelerating and optimizing process efficiency. Processes 2019, 7, 504. [CrossRef]

14. Rafique, R.; Poulsen, T.G.; Nizami, A.S.; Asam, Z.; Murphy, J.D.; Kiely, G. Effect of thermal, chemical and thermo-chemical pre-treatments to enhance methane production. Energy 2010, 35, 4556-4561. [CrossRef]

15. Luste, S.; Heinonen-Tanski, H.; Luostarinen, S. Co-digestion of dairy cattle slurry and industrial meat-processing by-products-effect of ultrasound and hygienization pre-treatments. Bioresour. Technol. 2012, 104, 195-201. [CrossRef] [PubMed]

16. Luste, S.; Luostarinen, S. Enhanced methane production from ultrasound pre-treated and hygienized dairy cattle slurry. Waste Manage. 2011, 31, 2174-2179. [CrossRef]

17. Climent, M.; Ferrer, I.; del Baeza, M.M.; Artola, A.; Vazquez, F.; Font, X. Effects of thermal and mechanical pretreatments of secondary sludge on biogas production under thermophilic conditions. Chem. Eng. J. 2007, 133, 335-342. [CrossRef]

18. Edstrom, M.; Nordberg, A.; Thyselius, L. Anaerobic treatment of animal byproducts from slaughterhouses at laboratory and pilot scale. Appl. Biochem. Biotechnol. 2003, 109, 127-138. [CrossRef]

19. Hejnfelt, A.; Angelidaki, I. Anaerobic digestion of slaughterhouse by-products. Biomass Bioenergy 2009, 33, 1046-1054. [CrossRef]

20. Luste, S.; Luostarinen, S.; Sillanpää, M. Effect of pre-treatments on hydrolysis and methane production potentials of by-products from meat-processing industry. J. Hazard. Mater. 2009, 164, 247-255. [CrossRef]

21. Rodriguez-Abalde, A.; Fernandez, B.; Silvestre, G.; Flotats, X. Effects of thermal pre-treatments on solid slaughterhouse waste methane potential. Waste Manage. 2011, 31, 1488-1493. [CrossRef]

22. Ajandouz, E.H.; Desseaux, V.; Tazi, S.; Puigserver, A. Effect of temperature and pH on the kinetics of caramelisation, protein cross-linking and Maillard reactions in aqueous model systems. Food Chem. 2008, 107, 1244-1252. [CrossRef]

23. Mersad, A.; Lewandowski, R.; Heyd, B.; Decloux, M. Colorants in the sugar industry: Laboratory preparation and spectrometric analysis. Int. Sugar J. 2003, 105, 269-281.

24. Martins, S.I.F.S.; Boekel, M.A.J.S. A kinetic model for the glucose/glycine Maillard reaction pathways. Food Chem. 2005, 90, 257-269. [CrossRef]

25. Michalska, A.; Honke, J.; Lysiak, G.; Andlauer, W. Effect of drying parameters on the formation of early and intermediate stage products of the Maillard reaction in different plum (Prunus domestica L.) cultivars. LWT Food Sci. Technol. 2016, 65, 932-938. [CrossRef]

26. Kung, L., Jr.; Shaver, R.D.; Grant, R.J.; Schmidt, R.J. Silage review: Interpretation of chemical, microbial, and organoleptic components of silages. J. Dairy Sci. 2018, 101, 4020-4033. [CrossRef] [PubMed]

27. Banks, C.; Heaven, S.; Zhang, Y.; Baier, U. Food Waste Digestion: Anaerobic Digestion of Food Waste for a Circular Economy; IEA Bioenergy, Task 37; International Energy Agency (IEA) and MaREI Centre University College Cork: Cork, Ireland, 2018; Available online: https://www.ieabioenergy.com/publications/food-wastedigestion-anaerobic-digestion-of-food-waste-for-a-circular-economy/ (accessed on 16 July 2020).

28. Morales-Polo, C.; Cledera-Castro, M.D.M.; Moratilla Soria, B.Y. Reviewing the anaerobic digestion of food waste: From waste generation and anaerobic process to its perspectives. Appl. Sci. 2018, 8, 1804. [CrossRef]

29. Mirmohamadsadeghi, S.; Karimi, K.; Tabatabaei, M.; Aghbashlo, M. Biogas production from food wastes: A review on recent developments and future perspectives. Bioresour. Technol. Rep. 2019, 7, 100202. [CrossRef]

30. Baek, G.; Kim, D.; Kim, J.; Kim, H.; Lee, C. Treatment of cattle manure by anaerobic co-digestion with food waste and pig manure: Methane yield and synergistic effect. Int. J. Environ. Res. Public Health 2020, 17, 4737. [CrossRef]

31. Hegde, S.; Trabold, T.A. Anaerobic digestion of food waste with unconventional co-substrates for stable biogas production at high organic loading rates. Sustainability 2019, 11, 3875. [CrossRef]

32. Xu, F.Q.; Li, Y.Y.; Ge, X.M.; Yang, L.C.; Li, Y. Anaerobic digestion of food waste-Challenges and opportunities. Bioresour. Technol. 2018, 247, 1047-1058. [CrossRef] 
33. Chow, W.L.; Chong, S.; Lim, J.W.; Chan, Y.J.; Chong, M.F.; Tiong, T.J.; Chin, J.K.; Pan, G.-T. Anaerobic co-digestion of wastewater sludge: A review of potential co-substrates and operating factors for improved methane yield. Processes 2020, 8, 39. [CrossRef]

34. Atandi, E.; Rahman, S. Prospect of anaerobic co-digestion of dairy manure: A review. Environ. Technol. Rev. 2012, 1, 127-135. [CrossRef]

35. Zarkadas, I.S.; Sofikiti, A.S.; Voudrias, E.A.; Pilidis, G.A. Thermophilic anaerobic digestion of pasteurised food wastes and dairy cattle manure in batch and large volume laboratory digesters: Focussing on mixing ratios. Renew. Energy 2015, 80, 432-440. [CrossRef]

36. Pagliaccia, P.; Gallipoli, A.; Gianico, A.; Gironi, F.; Montecchio, D.; Pastore, C.; di Bitonto, L.; Braguglia, C.M. Variability of food waste chemical composition: Impact of thermal pre-treatment on lignocellulosic matrix and anaerobic biodegradability. J. Environ. Manage. 2019, 236, 100-107. [CrossRef] [PubMed]

37. Banks, C.J.; Zhang, Y. Technical Report: Optimising Inputs and Outputs from Anaerobic Digestion Processes; Defra Project Code WR0212 (Department for Environment, Food and Rural Affairs, London, UK); University of Southampton: Southampton, UK, 2010. Available online: http://randd.defra.gov.uk/Document.aspx? Document=WR0212_8889_TRP.pdf (accessed on 10 September 2020).

38. Zhang, Y.; Kusch-Brandt, S.; Gu, S.; Heaven, S. Particle size distribution in municipal solid waste pre-treated for bioprocessing. Resources 2019, 8, 166. [CrossRef]

39. Gonzalez-Estrella, J.; Asato, C.M.; Jerke, A.C.; Stone, J.J.; Gilcrease, P.C. Effect of structural carbohydrates and lignin content on the anaerobic digestion of paper and paper board materials by anaerobic granular sludge. Biotechnol. Bioeng. 2017, 114, 951-960. [CrossRef]

40. Yuan, X.; Wen, B.; Ma, X.; Zhu, W.; Wang, X.; Chen, S.; Cui, Z. Enhancing the anaerobic digestion of lignocellulose of municipal solid waste using a microbial pretreatment method. Bioresour. Technol. 2014, 154, 1-9. [CrossRef]

41. Zhang, Y.; Banks, C.J.; Heaven, S. Anaerobic digestion of two biodegradable municipal waste streams. J. Environ. Manage. 2012, 104, 166-174. [CrossRef]

42. Walker, M.; Zhang, Y.; Heaven, S.; Banks, C.J. Potential errors in the quantitative evaluation of biogas production in anaerobic digestion processes. Bioresour. Technol. 2009, 100, 6339-6346. [CrossRef]

43. Symons, G.E.; Buswell, A.M. The methane fermentation of carbohydrates. J. Am. Chem. Soc. 1933, 55, 2028-2036. [CrossRef]

44. APHA. Standard Methods for the Examination of Water and Wastewater; American Public Health Association: Washington, DC, USA, 2005.

45. Hansen, K.H.; Angelidaki, I.; Ahring, B.K. Anaerobic digestion of swine manure: Inhibition by ammonia. Water Res. 1998, 32, 5-12. [CrossRef]

46. US EPA. Method 9071B: N-Hexane Extractable Material (HEM) for Sludge, Sediment, and Solid Samples. Test Methods for Evaluating Solid Waste, Physical/chemical Methods; US EPA SW-846 Compendium; US Environmental Protection Agency: Washington, DC, USA, 1998.

47. Van Soest, P.J.; Robertson, J.B.; Lewis, B.A. Methods for dietary fiber, neutral-detergent fiber and non-starch polysaccharides in relation to animal nutrition. J. Dairy Sci. 1991, 74, 3583-3597. [CrossRef]

48. Kitcherside, M.A.; Glen, E.F.; Webster, A.J.F. FibreCap: An improved method for the rapid analysis of fibre in feeding stuffs. Anim. Feed Sci. Tech. 2000, 86, 125-132. [CrossRef]

49. Mousavioun, P.; Doherty, W.O.S. Chemical and thermal properties of fractionated bagasse soda lignin. Ind. Crops Prod. 2010, 31, 52-58. [CrossRef]

50. Achinas, S.; Li, Y.; Achinas, V.; Euverink, G.J.W. Biogas potential from the anaerobic digestion of potato peels: Process performance and kinetics evaluation. Energies 2019, 12, 2311. [CrossRef]

51. Cuetos, M.J.; Gómez, X.; Martínez, E.J.; Fierro, J.; Otero, M. Feasibility of anaerobic co-digestion of poultry blood with maize residues. Bioresour. Technol. 2013, 144, 513-520. [CrossRef] [PubMed]

52. Kramer, S.L.; Waibel, P.E.; Behrends, B.R.; El Kandelgy, S.M. Amino acids in commercially produced blood meals. J. Agr. Food Chem. 1978, 26, 979-981. [CrossRef] [PubMed]

53. Ramsay, I.R.; Pullammanappallil, P.C. Protein degradation during anaerobic wastewater treatment: Derivation of stoichiometry. Biodegradation 2001, 12, 247-256. [CrossRef]

54. Atelge, M.; Atabani, A.; Banu, J.R.; Krisa, D.; Kaya, M.; Eskicioglu, C.; Kumar, G.; Lee, C.; Yildiz, Y.S.; Unalan, S.; et al. A critical review of pretreatment technologies to enhance anaerobic digestion and energy recovery. Fuel 2020, 270, 117494. [CrossRef] 
55. Schirmer, M.; Jekle, M.; Becker, T. Starch gelatinization and its complexity for analysis. Starch 2015, 67, 30-41. [CrossRef]

56. Liu, Q.; Tarn, R.; Lynch, D.; Skjodt, N.M. Physicochemical properties of dry matter and starch from potatoes grown in Canada. Food Chem. 2007, 105, 897-907. [CrossRef]

57. Sveinbjornsson, J.; Murphy, M.; Uden, P. In vitro evaluation of starch degradation from feeds with or without various heat treatments. Anim. Feed Sci. Tech. 2007, 132, 171-185. [CrossRef]

58. Eriksson, T.; Murphy, M. Ruminal digestion of leguminous forage, potatoes and fodder beets in batch culture: I. Fermentation pattern. Anim. Feed Sci. Tech. 2004, 111, 73-88. [CrossRef]

59. Zhu, F.; Hua, Y.; Li, G. Physicochemical properties of potato, sweet potato and quinoa starch blends. Food Hydrocoll. 2020, 100, 105278. [CrossRef]

60. Ai, Y.; Jan, J.-I. Gelatinization and rheological properties of starch. Starch 2014, 67, 213-224. [CrossRef]

61. Wilkins, K. Volatile organic compounds from household waste. Chemosphere 1994, 29, 47-53. [CrossRef]

62. Agapiou, A.; Vamvakari, J.P.; Andrianopoulos, A.; Pappa, A. Volatile emissions during storing of green food waste under different aeration conditions. Environ. Sci. Pollut. Res. 2016, 23, 8890-8901. [CrossRef] [PubMed]

63. Song, H.; Zhang, Y.; Kusch-Brandt, S.; Banks, C.J. Comparison of variable and constant loading for mesophilic food waste digestion in a long-term experiment. Energies 2020, 13, 1279. [CrossRef]

64. Holliger, C.; Alves, M.; Andrade, D.; Angelidaki, I.; Astals, S.; Baier, U.; Bougrier, C.; Buffière, P.; Carballa, M.; De Wilde, V.; et al. Towards a standardization of biomethane potential tests. Water Sci. Technol. 2016, 74, 2515-2522. [CrossRef] [PubMed]

65. Koch, K.; Hefner, S.D.; Weinrich, S.; Astals, S.; Holliger, C. Power and limitations of biochemical methane potential (BMP) tests. Front. Energy Res. 2020, 8, 63. [CrossRef]

Publisher's Note: MDPI stays neutral with regard to jurisdictional claims in published maps and institutional affiliations. 